\title{
The Vegetable Variety Navigator Decision-support Tool: An Interactive Visualization of Variety Trial Meta-analysis Results
}

\author{
Ali Loker ${ }^{1}$ and Sam E. Wortman ${ }^{2}$
}

\begin{abstract}
AdDITIONAL INDEX wORDs. Brassica olevacea, broccoli, Capsicum annuum, cucumber, Cucumis sativus, variety evaluation, sweet pepper

SumMARY. Variety trials provide growers with critical insight about how a specific variety might perform on their farm. Unfortunately, local variety trial data are often limited for specialty crop growers, especially those located outside of major production regions. One possible solution to this problem is to aggregate and synthesize existing variety trial results from many regions to help inform crop variety choices in regions without these data. We performed a systematic literature review and meta-analysis of all publicly available variety trial data for broccoli (Brassica olevacea), cucumber (Cucumis sativus), and sweet pepper (Capsicum annuиm) to identify broadly adapted, high-yielding, and high-quality varieties of each crop. We extracted data from 288 sources and calculated mean relative yield and/or quality estimates for 85 broccoli, 104 cucumber, and 144 pepper varieties that were evaluated across a minimum of three distinct locations. Results of this meta-analysis were used to develop the Vegetable Variety Navigator-an online decision-support tool that allows users to search and compare the mean and potential range of yield and quality performance for specific varieties. Users can also explore an interactive map to discover how variety performance is influenced by region, climate, and soil texture. The Vegetable Variety Navigator distills an otherwise overwhelming amount of variety trial data into a user-friendly web tool for growers that is intended to complement, not replace, existing sources of information about local variety performance.
\end{abstract}

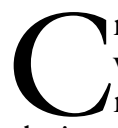
rop variety trials provide growers with valuable performance data to help inform variety choices for their farms (Pellack and Karlen, 2017; Williams and Roberts, 2002). Variety trials can also inform breeding efforts (Pellack and Karlen, 2017), which can accelerate progress toward food stability, climate change

Received for publication 13 Jan. 2021. Accepted for publication 5 May. 2021

Published online 23 June 2021

${ }^{1}$ Doctor of Plant Health Program, University of Nebraska-Lincoln, 279 Plant Sciences Hall, Lincoln, NE 68583

${ }^{2}$ Department of Agronomy and Horticulture, University of Nebraska-Lincoln, 279 Plant Sciences Hall, Lincoln, NE 68583

This research was funded in part by the Nebraska Agricultural Experiment Station with funding from the Hatch Act (accession 1014303) through the U.S. Department of Agriculture, National Institute of Food and Agriculture.

S.E.W. is the corresponding author. E-mail: swortman@unl.edu.

This is an open access article distributed under the CC BY-NC-ND license (https://creativecommons. org/licenses/by-nc-nd/4.0/).

https://doi.org/10.21273/HORTTECH04799-21 resilience, resource efficiency, and other complex agricultural challenges. The objective of variety trials is to evaluate varieties in specific environments where each environment encompasses a combination of the variability introduced by the location and season (Acquaah, 2009), which is often defined as siteyears. Regional collaborations can offer results from multiple years and diverse locations, thereby greatly expanding the inference space and applicability of variety trial results (Rangarajan, 2002). The current approach to variety trials includes the use of check varieties, replicated experimental design, and common production practices, as well as data collection and statistical analysis (Williams and Roberts, 2002). Yield is typically the most important and common trait evaluated during variety trials, although food quality and consumer preference are also important evaluation criteria, especially for fruit and vegetable crops (Brown et al., 2020).

The majority of vegetable variety trials are conducted at a single location. As recent examples, O'Connell
(2021) evaluated eight varieties of lettuce (Lactuca sativa) in field and high-tunnel systems at one location in Georgia. Afton et al. (2020) evaluated 45 varieties of lettuce at one location in Louisiana. Boyhan et al. (2020) compared 13 pepper (Capsicum annumm) varieties at one location in Georgia. Warren et al. (2015) studied 15 tomato (Solanum lycopersicum) varieties at one location in New Hampshire. Singlelocation variety trials are common for a good reason: conducting variety trials is expensive and time-intensive, and it is not possible to evaluate all varieties of interest with a single trial or in all desired environments (Brown et al., 2020). However, the inference space of results from a single-location variety trial is realistically limited to that single farm or others very similar to it in terms of climate, soil, and management. Although university-sponsored trials are often considered impartial, reliable sources of variety and location-specific performance data (Maynard, 2002; Pellack and Karlen, 2017; Williams and Roberts, 2002), fewer trials are conducted today because of reduced public research funding, fewer extension personnel, and fewer public vegetable breeders (Williams and Roberts, 2002). In addition, Brown et al. (2020) noted that some researchers may be reluctant to share raw data for fear of misrepresentation or because of resource constraints (Brown et al., 2020). There is also a lack of standardization for variety trial reporting (Brown et al., 2020; Rangarajan, 2002; Williams and Roberts, 2002) that limits comparisons among studies. The reduced availability and standardization of trial data contribute to widespread limitations in the long-term integration of data, as identified by Rangarajan (2002).

Results of individual variety trials can be extrapolated by aggregating data and using statistical models to predict and explain variety performance in other environments using environmental and genotypic covariates (Brown et al., 2020). van Etten et al. (2019) evaluated common bean (Phaseolus vulgaris), durum wheat (Triticum dur$u m$ ), and bread wheat (Triticum aestivum) in Nicaragua, Ethiopia, and India, respectively, using crowdsourced data. During this study, farmers categorically ranked varieties on their farm and researchers developed useful climatic models to extrapolate results 
and variety recommendations across locations (van Etten et al., 2019). Lyon et al. (2020) used an analysis of variance to assess the adaptability of squash (Cucurbita moschata), broccoli (Brassica oleracea), and carrot (Daucus carota) varieties across dozens of on-farm locations in several states within their breeding network for organic vegetables. The adaptability analysis was used to identify broadly adapted varieties (those that perform well in most environments) and specifically adapted varieties (those that perform well specifically in high-yielding or low-yielding environments). They found the adaptability analysis to be useful for quantitative variables, like yield, but less valuable for qualitative variables, like flavor (Lyon et al., 2020). Munaro et al. (2020) aggregated data from 748 regional wheat (Triticum) variety performance trials across 92 locations and 19 years and used variance partitioning to identify the relative influences of regional climate, management, and genetics on variety traits. Climate and management explained the majority of variation in yield, whereas genetics explained only $2 \%$ of the variation (Munaro et al., 2020). Laurent et al. (2015) used a meta-analysis and mixed-effect models to compare potential yields of different energy crop species using direct (within study) and indirect (among study) comparisons to develop a relative ranking of the most promising crops. A similar meta-analysis approach may be useful for comparing the yield and quality of vegetable varieties within and among studies and regions. Overall, there have been far fewer efforts, particularly for specialty crops compared with field crops, to aggregate variety trial data across studies, networks, regions, and countries. Moreover, specialty crop variety trial data that are publicly available are disaggregated across countless sources and not synthesized in a way that can aid grower decision-making.

To address this gap, we aimed to aggregate and synthesize vegetable variety trial data from around the world, explore descriptive and explanatory trends, and present a synthesis of trial results in a user-friendly online decision-support tool. Our specific objectives were to conduct a systematic literature review and extract yield and quality data from publicly available broccoli, cucumber (Cucumis sativus), and sweet pepper variety trials; to analyze these data and make indirect, relative comparisons between varieties from different studies, environments, and seasons; to identify potential explanatory relationships between local conditions and yield; and to visualize these data in a free online tool for growers, extension personnel, researchers, breeders, and other interested parties.

\section{Materials and methods}

Literature ReVIew. Yield and quality data for broccoli, cucumber, and sweet pepper varieties were collected through a systematic literature review. A meta-analysis of data extracted from the literature was conducted to produce relative yield and quality (if available) response values for each variety to indirectly assess performance across studies. The literature search was conducted using an academic search engine (Google Scholar; Google, Mountain View, CA); separate searches were conducted for each crop. Search terms included the common name of the crop plus "variety trial," "cultivar evaluation," "variety evaluation," or "cultivar trial" in all fields. A separate search was conducted for each of these search terms. A general Internet search was also conducted for each crop using the common name of the crop plus "variety trial university extension" to capture extension publications that were not retrieved by the academic search engine. Reports from any publication year and location were included for consideration. These reports consisted of original refereed research articles, extension publications, theses and dissertations, and review article (if original data were included). Patents and citations were excluded.

Additional requirements for inclusion in the analysis were that the study: 1) included a third-party research partner (often university, extension, or nonprofit; industry trials were excluded), 2) included at least three commercially available varieties, 3 ) presented data for yield and/or quality parameters, 4) was published in English or Spanish, and 5) full text was available online or through the University of Nebraska Library. The results were sorted by relevance and the first 300 search results were considered for each set of search terms. Searches were also conducted in several specific databases to complement the academic search engine and ensure completeness; these included: U.S. Department of Agriculture (USDA) Current Research Information System (using "variety trial" AND "broccoli" OR “pepper" OR "cucumber" as search terms), eOrganic variety trial reports, and the Midwest Vegetable Trial Reports. We extracted data from a total of 288 sources for the meta-analysis (Supplemental File 1).

DATa EXTRACTION AND ANALYSIS. Yield and/or quality data were extracted from selected studies and coded by crop, variety, study year and location, growing environment (i.e., open field or hoophouse/high tunnel), and number of site-years. Data on soil texture were also recorded when available. A web-based tool (WebPlot Digitizer version 4.3; Automeris, Pacifica, CA) was used to extract and approximate data when presented in graphs. Data were later grouped according to crop and variety to produce sufficient replication for meta-analysis.

Data were extracted from three databases to compile coordinates, soil textures, and aridity index values (ratio of precipitation to evapotranspiration) for studies when they were not provided. A web-based tool was used to geocode study locations (Geocodio; Dotsquare, Arlington, VA). USDA soil texture classes for each study location were obtained from the International Soil Reference and Information Center's Data Hub (Hengl et al., 2017) and global aridity index information was obtained from the Global Aridity Index dataset (Trabucco and Zomer, 2019). Soil texture and aridity index data were extracted using a geographic information system software (QGIS version 3.10; QGIS Project, Chicago, IL).

Response ratios for yield were determined for each variety within a study by dividing the yield of a particular variety by the average yield of all other varieties included in the study. If a cucumber variety was identified specifically as a pickling or slicing type, then the yield of that variety was only compared with the average yield of the same type (pickling or slicing) in that study. Response ratios were calculated for each discrete variety by site-year combination in a study and treated as independent observations within the meta-analysis. The response ratios were linearized, and normality was improved by taking the natural log of the response 
ratios (Hedges et al., 1999). This process was also used to produce response ratios for quality for varieties when these data were available.

We enlisted a categorical bootstrapping approach for the meta-analysis because of the small sample size of our response groups (e.g., individual varieties) and the variability of methods (e.g., pest management, production system) used in studies included in the meta-analysis (Borenstein et al., 2009). Nonparametric bootstrap confidence intervals (95\%) of yield and quality response ratios were calculated for varieties tested in a minimum of three distinct environments using a first-order normal distribution and 4999 iterations ("boot" package; $\mathrm{R}$ version 3.6.2; R Foundation, Vienna, Austria) (Adams et al., 1997). A total of 85 broccoli, 104 cucumber, and $144 \mathrm{sw}$ eet pepper varieties were included in the analysis for yield and/or quality. Yield and quality response ratios were back-transformed and reported as percentages relative to the mean yield of all other varieties in the analyzed studies. A mixed-effect meta-regression analysis was also conducted to explore the potential correlation between relative yield and aridity index when there were sufficient data available for an individual variety ("metafor" package, $\mathrm{R}$ version 3.6.2; R Foundation). A test to determine the heterogeneity of residuals was conducted (reported with $Q_{E}$ statistic), and a test of moderators was conducted to determine the potential influence of the aridity index moderator on yield (reported with $Q_{M}$ statistic) (Viechtbauer, 2010). We aimed to perform a categorical bootstrap analysis using soil textural classification as the moderator, but there was insufficient replication of soil texture within varieties to explore the possible effects of soil texture on yield or quality.

Analysis of relative yield and quality among studies assumes that comparable yield and quality data collection methods were used across studies. However, variability in harvest timing and response variables measured is unavoidable and would contribute to random error in this meta-analysis. Similarly, calculating a relative yield and quality for varieties within studies is confounded by the other varieties included in that same study. This analysis assumes that the vast majority of variety trials compared vegetables of similar type and end use (e.g., slicing cucumbers, fall broccoli, or early peppers). Deviation from this assumption would contribute to random error and would be reflected in the size of confidence intervals around each relative mean.

VARIETY SELECTION DECISIONSUPPORT TOOL. Mean relative yield and quality values and their corresponding 95\% bootstrap confidence intervals were integrated into an online decision-support tool called the Vegetable Variety Navigator (Wortman and Loker, 2020). This tool allows growers and other users to view relative yield and quality data via interactive charts and maps hosted by a data visualization platform (Tableau Public version 2020.3.0; Tableau Software, Mountain View, CA). These data can help growers decide the best variety for their operation, in combination with other personal decision-making factors, such as pest resistance, time to maturity, and local availability.

The Vegetable Variety Navigator consists of two main sections: graphical summaries of mean relative yield and quality potentials (Fig. 1) and a dynamic map (Fig. 2). The graphical summaries can help users compare the relative yield or quality potentials of various broccoli, cucumber, and sweet pepper varieties by selecting multiple varieties of interest from the right-side menu bar. Additional information is provided in a pop-up box that appears when a user hovers over a data point. Data from all studies are also presented in map-form to allow users to explore possible relationships among yield and quality, region, soil texture, and aridity index. The map section also allows users to view individual study data for varieties that were not included in the relative yield/quality potential calculations (found in the graphical summaries) because of insufficient distinct environments (i.e., fewer than three). Citations for individual studies are also available in the map view to allow users to view details about the experimental design and other information of interest. Users may also use the filters on the right-side menu bar to narrow results by crop, variety, soil texture, and/or aridity index (Fig. 2) to obtain results most relevant to their farms.

\section{Results and discussion}

Relative YIELD AND QUALITY. Varieties were categorized as having low, moderate, or high relative yield/ quality potentials based on their confidence intervals and color-coded to succinctly communicate these results to users (Table 1). Varieties with confidence intervals that only included a range of values less than zero were categorized as having low relative yield or quality potential. These varieties performed consistently worse than the others included in a trial for direct comparison. Varieties with confidence intervals that contained only values greater than zero were categorized as having high relative yield or quality potential; these varieties consistently

Table 1. Parameters for determination and identification of low, moderate, and high relative yield or quality potential in the Vegetable Variety Navigator and the relative proportion of varieties identified as such for broccoli, cucumber, and pepper.

\begin{tabular}{|c|c|c|c|c|c|c|c|c|}
\hline \multirow[b]{3}{*}{ Potential } & \multirow{3}{*}{$\begin{array}{c}\text { Confidence } \\
\text { interval bounds }\end{array}$} & \multirow{3}{*}{$\begin{array}{l}\text { Color in } \\
\text { online tool }\end{array}$} & \multicolumn{6}{|c|}{ Relative proportion of varieties (\%) } \\
\hline & & & \multicolumn{2}{|c|}{ Broccoli } & \multicolumn{2}{|c|}{ Cucumber } & \multicolumn{2}{|c|}{ Pepper } \\
\hline & & & Yield & Quality & Yield & Quality & Yield & Quality \\
\hline $\begin{array}{l}\text { Moderate relative } \\
\text { yield/quality }\end{array}$ & Contains 0 & Gray & 72 & 75 & 66 & 84 & 69 & 74 \\
\hline
\end{tabular}




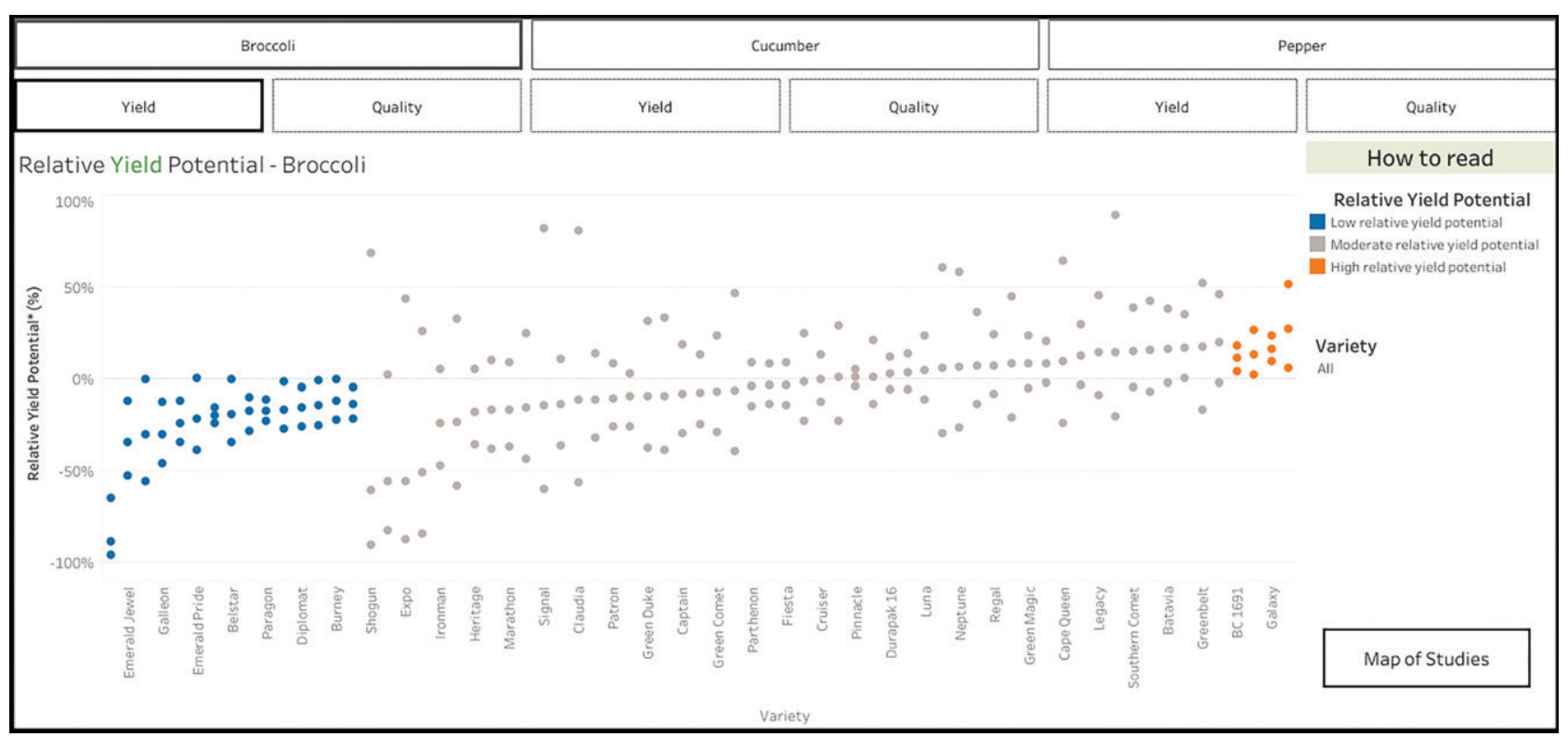

Fig. 1. A screenshot of the user interface for the graphical summaries section of the Vegetable Variety Navigator. Users can visualize the mean and $\mathbf{9 5 \%}$ confidence interval for relative yield and quality potential for broccoli, cucumber, and pepper variety data. Varieties were categorized as having low (blue), moderate (gray), or high (orange) relative yield or quality potential depending on performance relative to other varieties in trials included in the analysis.

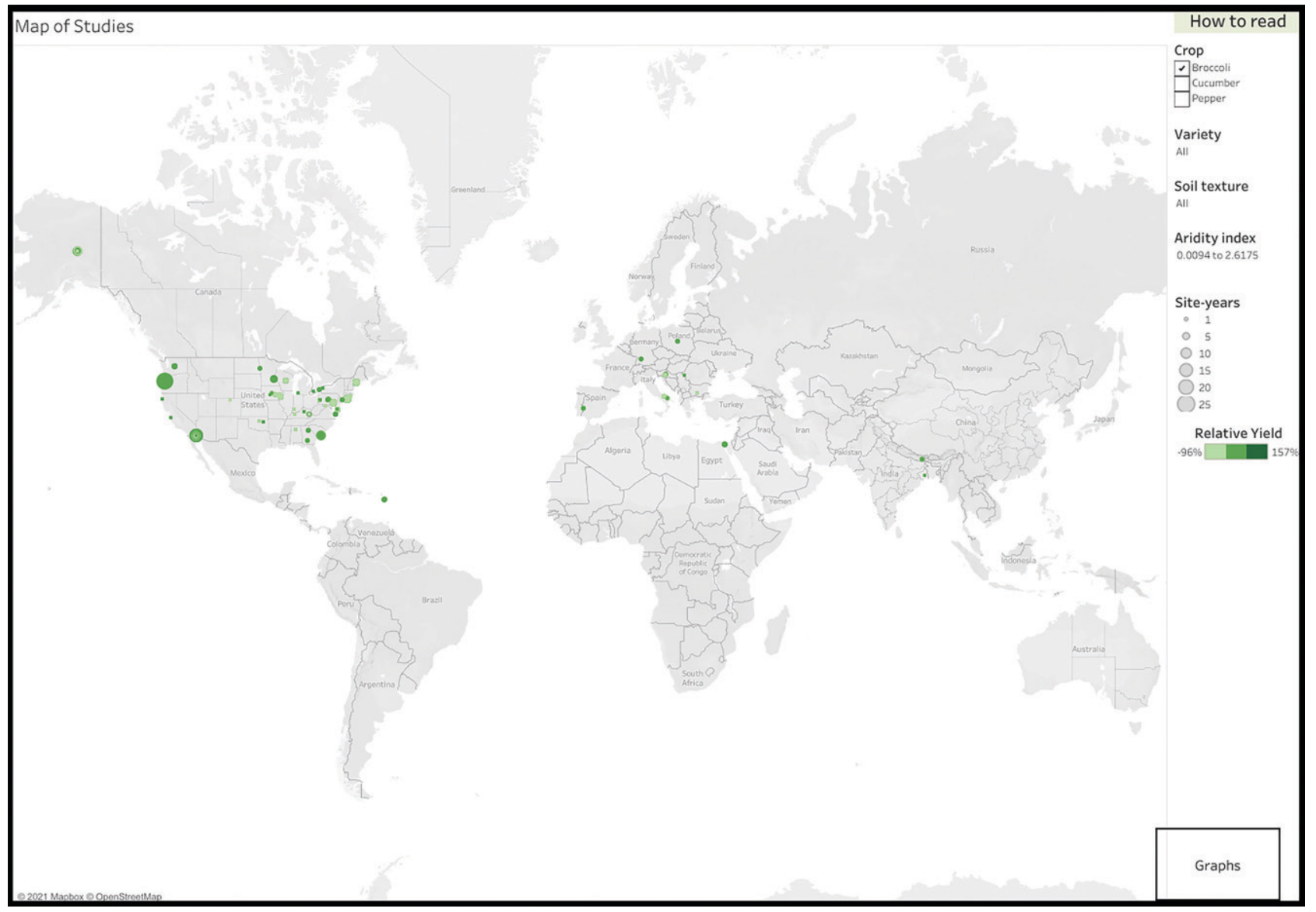

Fig. 2. A screenshot of the user interface for the mapping section of the Vegetable Variety Navigator. Users can visualize the differences in relative yield and quality means for broccoli, cucumber, and pepper varieties across locations, climates, and soil textures. The relative size of each data point provides information about the number of locations and years (i.e., site-years) contributing to the calculated mean (larger dots indicate more replication). The shade of green of each data point indicates the relative performance of that variety among locations on the map (darker green dots indicate better performance). 
outperformed others included in the same study. The most common classification was moderate relative yield or quality potential, which included those varieties with a confidence interval range including zero. These varieties did not perform significantly better or worse than the peer varieties from the same trial. The percentages of varieties categorized as having low, moderate, or high yield and quality potentials for each crop are summarized in Table 1. The number and size of categories are not absolute; instead, they are intended to aid the interpretation of meta-analysis results for end-users.

The range of the confidence interval can be interpreted as the adaptability of a particular variety. Varieties with smaller ranges are assumed to be more widely adapted than those with larger ranges. For example, a confidence interval with a smaller range indicates more consistent performance across environments than an interval with a large range. Growers can use this adaptability information in conjunction with the relative yield or quality potentials to select suitable varieties for their operations with consideration for their own thresholds for risk (i.e., broadly adapted varieties are less risky, but narrowly adapted varieties may perform exceptionally well in very specific locations).

Among 69 broccoli varieties analyzed for yield, Green Gold, Galaxy, Liberty, and BC 1691 were consistently high-yielding. In contrast, the highest-quality broccoli varieties (among 57 analyzed for quality) were Emerald Pride, Lieutenant, Southern Comet, Patriot, Luna, Windsor, and Packman (Supplemental Table 1). No broccoli varieties were identified as both reliably high-yielding and highquality across environments. Of the 99 cucumber varieties analyzed for yield, Alibi, Liszt, Expedition, Journey, Socrates, Tasty Jade, EarliPik 14, Pik Rite, Sprint 440 , and Score had high relative yield potential. The quality potential among 72 analyzed cucumber varieties was less variable but consistently above average for Eureka, Journey, Dasher II, Speedway, Calypso, Sprint 440, Spear It, and Amour (Supplemental Table 2). Interestingly, the mean relative yield potential was less than $0 \%$ for six of these eight high-quality cucumber varieties, highlighting the common tradeoff between crop yield and quality (Benbrook, 2009). Among
134 sweet pepper varieties analyzed for yield, 19 were identified as consistently high-yielding; those varieties included Ace, New Ace, Flamingo, Sweet Chocolate, Red Dawn, Colossal, Argo, Lady Bell, Honeybelle, Turnpike, Green Boy, Antebellum, Domino, Declaration, Sentry, Charisma, Excursion II, Boca, and PS 0994-1819. Sweet pepper varieties exhibiting consistently high quality (out of 111 analyzed) included Ma Belle, Snapper, Wizard, Belle Star, Four Corners, Currier, Alliance, Legionnaire, Patriot, Archimedes, Declaration, Heritage, Classic, and Outsider (Supplemental Table 3). Only 'Declaration' was identified as consistently high-yielding and high-quality (14 observations across 13 studies).

Relationship BETWEEN ARIDITY AND RELATIVE YIELD. A meta-regression was conducted to identify potential correlation between global aridity index (annual average 1970-2000) and relative yield data. Overall, results suggest that global aridity index is not a consistently useful explanatory variable for relative yield of broccoli, cucumber, or sweet pepper varieties across time and space. A significant relationship between aridity and relative yield was observed for one broccoli variety (HMX 4138: $Q_{M}=8.435, P<0.01$ ), three cucumber varieties (Indy: $Q_{M}=$ 9.105, $P<0.01$; Darlington: $Q_{M}=$ 6.568, $P=0.01$; Pik Rite: $Q_{M}=$ $4.071, P=0.04)$, and one sweet pepper variety (Blushing Beauty: $Q_{M}=$ 15.878, $P<0.001)$. However, the direction of the correlation between the aridity index and relative yield was not consistent among varieties, and the number of site-years contributing to these relationships was relatively small. It is noteworthy that the number of significant correlations-only 5 out of 291 tested $(1.7 \%)$ —was within the expected rate of spurious correlation or "false positives" (the margin of type 1 error is typically equal to the significance level, which, in this case, was $5 \%)$. The overwhelming lack of significant correlations and the inevitability of type 1 error seem to suggest that the aridity index is not a useful predictor of relative yield performance for broccoli, cucumber, or sweet pepper.

These results are similar to those of Kheiri et al. (2017), who did not observe a significant correlation between the annual aridity index and dryland wheat yield but did observe significant relationships between the seasonal aridity index and yield at only some stations. However, during an earlier study, Bannayan et al. (2010) found a positive correlation between the annual aridity index and yield for rainfed wheat and barley (Hordeum vulgare) in Iran. A significant correlation between the aridity index and yield on a seasonal scale was also observed at several sites during the wet season (Bannayan et al., 2010). Of the varieties for which a significant relationship between global aridity index and yield was observed during our meta-regression, only one study was conducted under rainfed conditions; the remaining studies performed irrigation or did not specify whether irrigation was used. Therefore, it is possible that the prevalent use of irrigation during the studies included in the meta-regression (and, more generally, for vegetable crops) affected the potential relationship between aridity and yield (more commonly observed in nonirrigated field crops). The lack of a significant relationship may also indicate that most commercially available varieties (like those included in this meta-analysis) are broadly adapted to diverse arid and humid environments.

EXAMPLE APPLICATION OF THE Vegetable Variety Navigator. Assume that vegetable growers near Lincoln, NE, are searching for a new cucumber variety for their farms. In addition to recommendations from seed companies, fellow growers, and Extension resources, the growers can now consult the Vegetable Variety Navigator to find a visual summary of all public yield and quality data for any varieties they may be considering (excluding newly released varieties for which public variety trial data are not yet available). After consulting local vegetable variety recommendations from the University of Nebraska Extension (Browning and Hodges, 2008), these growers have narrowed their search to Marketmore 76 and Dasher II.

A comparison of these two varieties in the graphical section of the tool (Fig. 1) revealed that Marketmore 76 is relatively low-yielding (mean relative yield of $-70 \%$ ) compared with Dasher II, which has moderate yield potential (mean relative yield of $-1 \%$ compared with its competitors) (Supplemental Table 1). Moreover, 'Dasher II' has exhibited average to above-average 
quality (ranging from $0 \%$ to $42 \%$ relative quality compared with competitors), whereas the quality of 'Marketmore 76' is consistently average ( $-5 \%$ to $8 \%$ quality change relative to competitors). Next, the growers would be advised to consult the map section of the tool (Fig. 2) to explore results for each variety across specific locations.

Using "proximity to Lincoln, Nebraska" as the criteria for evaluation, the growers would find 3 siteyears of data for 'Marketmore 76' in Wisconsin and 2 site-years of data in Ohio. In these locations, the average relative yield potential for 'Marketmore 76 ' ranged from $7 \%$ to $20 \%$, which is much greater than the range identified through the global dataset (an exploration of data from the southeast region of the United States helps explain the relatively low global yield estimate for 'Marketmore 76'). Relative quality from these nearby locations ranged from $-7 \%$ to $2 \%$ for 'Marketmore 76', which is consistent with its global range. Data for 'Dasher II' in closest proximity to Lincoln, $\mathrm{NE}$, include 1 site-year each from Missouri, Oklahoma, and Kentucky, and 2 site-years from Michigan. Across these locations, the average relative yield potential of 'Dasher II' ranged from $-25 \%$ to $49 \%$. Relative quality was available for only 2 site-years and ranged from $1 \%$ to $188 \%$ (compared with a global mean of $17 \%$ ).

This mapping exercise suggests that the Nebraska extension guide provides relatively accurate recommendations for 'Marketmore 76' and 'Dasher II' (based on data from the nearest locations), and both are likely acceptable varieties for these growers. 'Dasher II' seems to have greater yield and quality potential, but it may be less adaptable to specific conditions throughout the midwestern United States compared with 'Marketmore 76'. However, the broader adaptability of 'Dasher II' beyond the midwestern United States (exhibited by its global relative yield range) may be beneficial considering the increasingly volatile and unpredictable weather associated with climate change. Finally, these growers could assign a weighted value to the results from specific locations based on latitude (as a proxy for important factors like daylength and nighttime temperatures), soil texture, or aridity index instead of solely depending on proximity to Lincoln, NE.

\section{Conclusions}

Variety trial data are critically important to vegetable growers but are increasingly difficult to source and extrapolate across production regions. The Vegetable Variety Navigator decision-support tool aims to synthesize an otherwise overwhelming amount of variety trial data into a user-friendly web tool for growers that is intended to complement, not replace, existing sources of information about local variety performance. The Vegetable Variety Navigator will be periodically updated with data from new trials, and a subset of varieties will be ground-truthed in 2021 and 2022 through local on-farm variety trials in Nebraska. Users may also submit new variety trial data for consideration through the Vegetable Variety Navigator website to ensure that the database is accurate and complete. Finally, we anticipate adding additional locally important vegetable crops to the tool in the future, including tomato, sweet corn (Zea mays), and pumpkin (Cucurbita sp.).

\section{Literature cited}

Acquaah, G. 2009. Principles of plant genetics and breeding. Wiley, Hoboken, NJ.

Adams, D.C., J. Gurevitch, and M.S. Rosenberg. 1997. Resampling tests for meta-analysis of ecological data. Ecology 78:1277-1283, doi: 10.2307/2265879.

Afton, W.D., K.K. Fontenot, J.S. Kuehny, and C.E. Motsenbocker. 2020. Evaluation of yield, marketability, and nitrate levels of lettuce cultivars produced in southern Louisiana. HortTechnology 30:632-637, doi: 10.21273/HORTTECH04642-20.

Bannayan, M., S. Sanjani, A. Alizadeh, S.S. Lotfabadi, and A. Mohamadian. 2010. Association between climate indices, aridity index, and rainfed crop yield in northeast of Iran. Field Crops Res. 118:105-114, doi: 10.1016/j.fcr.2010.04.011

Benbrook, C. 2009. The impacts of yield on nutritional quality: Lessons from organic farming. HortScience 44:12-14, doi: 10.21273/HORTSCI.44.1.12.

Borenstein, M., L.V. Hedges, J.P.T. Higgins, and H.R. Rothstein. 2009. Introduction to meta-analysis. Wiley, Hoboken, NJ. doi: 10.1002/9780470743386.ch20.

Boyhan, G.E., C. McGregor, S. O'Connell, J. Biang, and D. Berle. 2020. A comparison of 13 sweet pepper varieties under an organic farming system. Hort Technology 30:135-143, doi: 10.21273/HORTTECH04455-19.

Brown, D., I. Van den Bergh, S. de Bruin, L. Machida, and J. van Etten. 2020. Data synthesis for crop variety evaluation. A review. Agron. Sustain. Dev. 40:25, doi: 10.1007/s13593-020-00630-7.

Browning, S. and L. Hodges. 2008. Selected vegetable cultivars for Nebraska. Univ. Nebraska NebGuide G1896. 5 Jan. 2021. <https://extensionpublications.unl.edu/ assets $/ \mathrm{html} / \mathrm{gl} 1896 /$ build/g1896.htm $>$.

Hedges, L.V., J. Gurevitch, and P.S. Curtis. 1999. The meta-analysis of response ratios in experimental ecology. Ecology 80:11501156, doi: 10.1890/0012-9658(1999)080 [1150:TMAORR]2.0.CO;2.

Hengl, T., J. Mendes de Jesus, G.B.M. Heuvelink, M. Ruiperez Gonzalez, M. Kilibarda, A. Blagotić, W. Shangguan, M.N. Wright, X. Geng, B. Bauer-Marschallinger, M.A. Guevara, R. Vargas, R.A. MacMillan, N.H. Batjes, J.G.B. Leenaars, E. Ribeiro, I. Wheeler, S. Mantel, and B. Kempen. 2017. SoilGrids $250 \mathrm{~m}$ : Global gridded soil information based on machine learning. PLoS One 12(2):e0169748, doi: 10.1371/ journal.pone.0169748.

Kheiri, M., S. Soufizadeh, A. Ghaffari, M. Aghaalikhani, and A. Eskandari. 2017. Association between temperature and precipitation with dryland wheat yield in northwest of Iran. Clim. Change 141:703-717, doi: 10.1007/s10584-017-1904-5.

Laurent, A., E. Pelzer, C. Loyce, and D. Makowski. 2015. Ranking yields of energy crops: A meta-analysis using direct and indirect comparisons. Renew. Sustain. Energy Rev. 46:41-50, doi: 10.1016/j.rser.2015. 02.023 .

Lyon, A., W. Tracy, M. Colley, P. Culbert, M. Mazourek, J. Myers, J. Zystro, and E.M. Silva. 2020. Adaptability analysis in a participatory variety trial of organic vegetable crops. Renew. Agr. Food Syst. 35:296-312, doi: $10.1017 /$ S1742170518000583.

Maynard, D.N. 2002. Enhancing the scope of vegetable cultivar evaluation in Florida. HortTechnology 12:560-561, doi: 10.21273/horttech.12.4.560.

Munaro, L.B., T.J. Hefley, E. DeWolf, S. Haley, A.K. Fritz, G. Zhang, L.A. Haag, A.J. Schlegel, J.T. Edwards, D. Marburger, P. Alderman, S.M. Jones-Diamond, J. Johnson, J.E. Lingenfelser, S.H. Unêda-Trevisoli, and R.P. Lollato. 2020. Exploring longterm variety performance trials to improve environment-specific genotype $\times$ management recommendations: A case-study for winter wheat. Field Crops Res. 255:107848, doi: 10.1016/j.fcr.2020.107848. 
O'Connell, S. 2021. Miniature head lettuce yield and anthocyanin concentration under high tunnels and the field in Georgia. HortTechnology 31:53-63, doi: 10.21273/HORTTECH04744-20.

Pellack, L.J. and D.L. Karlen. 2017. Iowa crop variety yield testing: A history and annotated bibliography. Crop Sci. 57:1984 1998, doi: 10.2135/cropsci2017.01.0009.

Rangarajan, A. 2002. Vigor or rigor? The competing goals of variety trials. HortTechnology 12:562-566, doi: 10.21273/ HORTTECH.12.4.562.

Trabucco, A. and R. Zomer. 2019. Global aridity index and potential evapotranspiration (ET0) Climate Database v2
(Version 3). figshare. Dataset. doi: 10.6084/m9.figshare.7504448.v3.

van Etten, J., K.d. Sousa, A. Aguilar, M. Barrios, A. Coto, M. Dell'Acqua, C. Fadda, Y. Gebrehawaryat, J.d. Gevel, A. Gupta, A.Y. Kiros, B. Madriz, P. Mathur, D.K. Mengistu, L. Mercado, J.N. Mohammed, A. Paliwal, M.E. Pè, C.F. Quirós, J.C. Rosas, N. Sharma, S.S. Singh, I.S. Solanki, and J. Steinke. 2019. Crop variety management for climate adaptation supported by citizen science. Proc. Natl. Acad. Sci. USA 116:4194-4199, doi: 10.1073/ pnas.1813720116.

Viechtbauer, W. 2010. Conducting metaanalyses in $\mathrm{R}$ with the metafor package. J.
Stat. Softw. 36(3):1-48, doi: 10.18637/ jss.v036.i03.

Warren, N.D., R.G. Sideman, and R.G. Smith. 2015. Performance of high tunnel tomato cultivars in northern New England. HortTechnology 25:139-146, doi: 10.21273/HORTTECH.25.1.139.

Williams, T.V. and W. Roberts. 2002. Is vegetable variety evaluation and reporting becoming a lost art? An industry perspective. HortTechnology 12:553-559, doi: 10.21273/horttech.12.4.553.

Wortman, S. and A. Loker. 2020. Vegetable Variety Navigator. 8 Jan 2021. <https://agronomy.unl.edu/VegetableVariety-Navigator $>$. 


\section{Supplemental File 1}

Studies included in the meta-analysis and online decision-support tool.

\section{Broccoli}

Antonova, G., I. Dimov, T. Dintcheva, H. Boteva, S. Masheva, V. Yankova, V. Kanazirska, G. Pevicharova, I. Tringovska, M. Michov, and O. Georgieva. 2010. Evaluation of the stability and the adaptability on the yield of broccoli cultivars grown under condition in monoculture and intercropping system. Cruciferae Nwsl. 29:16-18.

Boari, F., N. Calabrese, M. Renna, V. Cantore, and M.I. Schiattone. 2013. Effects of biofertilizers on gas exchange, yield and quality of some broccoli cultivars in organic farming. Acta Hort. 1005:397-404, doi: 10.17660/ ActaHortic.2013.1005.47.

Boches, P., D. Kean, P. Kusolwa, J. Myers, and J. Stang. 2006. Vegetable variety trials 2005. Oregon State Univ., Corvallis.

Brown, R. 2012. 2011 Vegetable variety report. 6 July 2020. <http://digitalcommons. uri.edu/riaes_bulletin/12>.

Butler, M. 1990. Broccoli variety trials 1989/1990. 6 July 2020. <http://hdl.handle. net/10150/221434>.

Butler, M. 1991. Broccoli variety trials 1990/1991. 6 July 2020. <http://hdl.handle. net $/ 10150 / 214484>$.

Butler, M. and N. Oebker. 1985. Yuma County broccoli trials 1984/1985. 6 July 2020. $<$ http:/hdl.handle.net/10150/214112>.

Butler, M. and N. Oebker. 1989. Broccoli variety trials 1988/1989. 6 July 2020 . $<$ http://hdl.handle.net/10150/214470>.

Butler, M., N. Oebker, and J. Davis. 1988. Broccoli variety trials 1987/1988. 6 July 2020. $<$ http://hdl.handle.net/10150/214269>.

Butler, M.D. and J.A. Davis. 1987. Broccoli downy mildew trials. 6 July 2020 . $<$ http://hdl.handle.net/10150/221456>.

Butler, M.D. and N.F. Oebker. 1987. Broccoli variety trials, Yuma Valley Agricultural Center. 1986. 6 July 2020. $<$ http://hdl.handle.net/10150/221255>.

Carolina Farm Stewardship Association. 2014. Piedmont and eastern NC organic broccoli variety trial, Fall 2014. 6 July 2020. $<$ https://www.carolinafarmstewards.org/ southeast-organic-seed-and-variety-trialsreport/ $>$.

Colorado State University. 2004. Broccoli. 10 July 2020. <https://specialtycrops.agsci.colostate.edu/broccoli/ $>$.

Conversa, G., C. Lazzizera, A. Bonasia, and A. Elia. 2019. Growth, N uptake and $\mathrm{N}$ critical dilution curve in broccoli cultivars grown under Mediterranean conditions. Scientia Hort. 244:109-121, doi: 10.1016/j.scienta.2018.09.034.

Coolong, T. 2015. Broccoli variety trial: Fall 2013. In: T. Coolong (ed.). 2014/2015 University of Georgia Vegetable Crops Research Report. Univ. Georgia, Athens.

El-Hamed, A. and M.W.M. Elwan. 2010. Genotype by environment interaction and phenotypic stability of yield and quality in broccoli (Brassica oleracea var. italica). J. Plant Production Mansoura Univ. 1:819-835, doi: 10.21608/jpp.2010.86411.

Farnham, M.W. and T. Björkman. 2011. Evaluation of experimental broccoli hybrids developed for summer production in the eastern United States. HortScience 46:858-863, doi: 10.21273/HORTSCI.46.6.858.

Farnham, M.W., A.P. Keinath, and M.A. Grusak. 2011. Mineral concentration of broccoli florets in relation to year of cultivar release. Crop Sci. 51:2721-2727, doi: 10.2135/cropsci2010.09.0556.

Fletcher, R.E. 1986. Commercial broccoli cultivars for tropical lowland environments. Proc. XXII Annu. Mtg. Caribbean Food Crops Soc., St. Lucia, 25-29 Aug. 1986, doi: 10.22004/ag.econ.261324.

Gajc-Wolska, J., T. Spiżewski, and A. Grabowska. 2013. The effect of seaweed extracts on the yield and quality parameters of broccoli (Brassica oleracea var. cymosa L.) in open field production. Acta Hort. 1009:83-89, doi: 10.17660/ActaHortic.2013.1009.9.

Goldy, R. and D. Francis. 2001. Broccoli yield trial. Southwest Michigan Res. Ext. Ctr., Benton Harbor.

Guan, W. 2020. Fall broccoli production in high tunnels. Midwest Vegetable Trial Reports. Paper 11. 10 July 2020. $<$ https://docs.lib.purdue.edu/mwvtr/1 $>$.

Harrison, H.F. and M.W. Farnham. 2013. Differences in tolerance of broccoli and cabbage cultivars to clomazone herbicide. HortTechnology 23:6-11, doi: 10.21273/HORT TECH.23.1.6.

Hatterman-Valenti, H., P. Mayland, L. Duppong, and S. Friedricks. 2003. Broccoli cultivar trial 2003. North Dakota State Univ., Fargo.

Hatterman-Valenti, H., P. Mayland, and S. Friedricks. 2002. Broccoli cultivar trial. North Dakota State Univ., Fargo.

Heather, D.W., J.B. Sieczka, M.H. Dickson, and D.W. Wolfe. 1992. Heat tolerance and holding ability in broccoli. J. Amer. Soc. Hort. Sci. 117:887-892, doi: 10.21273/JASHS.117.6.887.

Holloway, P.S., J. Hanscom, E. Gardiner, and G.E.M. Matheke. 2008. Annual vegetable trials 2008. 10 July 2020. <http:// hdl.handle.net/11122/2824>.
Howard, N. and J.C. Snyder. 2005. Fall broccoli cultivar trial, northwestern Kentucky. Univ. Kentucky, Lexington.

Ingratta, F.J. and W.A. Straver. 1978. Vegetable cultivar trials 1978. Ontario Ministry Agr. Food, Vineland Sta., ON, Canada.

Jett, L. 2015. Evaluation of broccoli cultivars for summer crown-cut production in West Virginia. Purdue Fruit Vegetable Res. Rep. Paper 117. 10 July 2020. < https://docs. lib.purdue.edu/fvtrials/117>.

Johnson, G. 2017. 2017 University of Delaware spring broccoli variety trial. Univ. Delaware Res. Educ. Ctr., Georgetown.

Johnson, G. and E. Ernest. 2010. 2010 University of Delaware fall broccoli variety trial. Univ. Delaware Res. Educ. Ctr., Georgetown.

Kean, D., J. Myers, and J. Stang. 2004. Vegetable variety trials 2003. Oregon State Univ. Ext., Corvallis.

Kemble, J., E. Vinson, and A. Caylor. 2012. Several broccoli varieties produce higher than market standard. Fall 2011 Commercial Fruit Vegetable Variety Trials Reg. Bull. 25.

Khan, B. and L. Carrier. 2015. Fall 2014 broccoli variety trial. Oklahoma State Univ., Stillwater.

Khan, B., L. Wells, B. Bostian, and F. Steiner. 2003. Fall 2002 broccoli variety trial. Oklahoma State Univ., Stillwater.

Kolbe, L. 2016. Summer broccoli variety trial. 10 July $2020 .<$ http://bit.ly/pfi_ horticulture $>$.

Kundu, P., A. Mukherjee, and N.C. Sahu. 2018. Suitable cultivars of broccoli, red cabbage, capsicum and french bean for alluvial tracts of West Bengal. J. Krishi Vigyan 7:197-202, doi: 10.5958/2349-4433.2018.00132.0.

Laemmlen, F.F. and K.S. Mayberry. 1984. Broccoli resistance to downy mildew. Calif. Agr. 38(11):17.

Lawson, V. 2001. Broccoli cultivar trial. Iowa State Univ., Fruitland.

Loughton, A., J. O'Sullivan, A.W. McKouwn, R.A. Brammall, R. Baker, W.J. Bouw, J. Packer, and G.E. Banfield. 1993. Vegetable cultivar trials 1992.10 July 2020. $<$ http://hdl.handle.net/10214/7303>.

Matheke, G.E.M., J. Hanscom, P.S. Holloway, and A. Gardiner. 2003. Vegetable cultivar trials 2003. 10 July 2020. $<$ http://hdl.handle.net/11122/2114>.

Matheke, G.E.M., J. Hanscom, P.S. Holloway, and E. Gardiner. 2006. Vegetable trials 2006. 10 July 2020. < http:// hdl.handle.net/11122/2818>.

McKenzie, L. 2013. Breeding an open pollinated broccoli for organic production systems using participatory methods. MS Thesis, Oregon State Univ., Corvallis.

Muehmer, J., B. Gillier Eagen, and R. Wright. 1988. Vegetable trial report. 10 July 2020. <http://hdl.handle.net/10214/5388>. 
Myers, J. and B. Yorgey. 2006. Broccoli breeding, evaluation and seed production: Report to the Oregon Processed Vegetable Commission, 2006-2007. Oregon State Univ., Corvallis.

Myers, J. and B. Yorgey. 2010. Broccoli breeding, evaluation and seed production: Report to the Oregon Processed Vegetable Commission, 2009-2010. Oregon State Univ., Corvallis.

Myers, J. and B. Yorgey. 2015. Broccoli breeding, evaluation and seed production 2015: OPVC Continuing Project Report. Oregon State Univ., Corvallis.

Nair, A., K. Lang, and M. Bilenky. 2018. Effect of row cover materials and cultivars in broccoli production systems. Iowa State Univ. Res. Demonstration Farms Prog. Rpt. 2018.

Northern Organic Vegetable Improvement Collaborative. 2010. 2010 Organic broccoli variety trial results. 10 July 2020. < https:// varietytrials.eorganic.info/node/578 $>$.

Northern Organic Vegetable Improvement Collaborative. 2011. 2011 Organic broccoli variety trial results. 10 July 2020. <https:// varietytrials.eorganic.info/node/572>.

Northern Organic Vegetable Improvement Collaborative. 2012. 2012 Organic broccoli variety trial results. 10 July 2020. <https:// varietytrials.eorganic.info/node/568 $>$.

O'Connell, S. and R. Tate. 2017. Winter broccoli and cauliflower under organic high tunnels in a humid, subtropical climate. HortScience 52:1511-1517, doi: 10.21273/HORTSCI12291-17.

Ordiales, E., D.J. Iglesias, M.V. Alarcón, L. Zajara, J. Gil, J.I. Gutiérrez, and J. Salguero. 2017. Characteristics defining broccoli cultivars from different seed producers. Int. J. Agron. 6: doi: 10.1155/2017/8216390.

Organic Seed Alliance. 2012. 2012 California organic variety trial report. 10 July 2020. <https://seedalliance.org/publications/ 2012-organic-variety-trials-report/ $>$.

PennState Extension. 2012. 2012 Broccoli variety trial. 10 July $2020 .<$ https://extension.psu.edu/2012-broccoli-variety-trial $>$.

Piya, S., A.R. Bajracharya, J.L. Mandal, and B.P. Choudhary. 2010. Varietal performance of broccoli for summer season production. Nepalese Hortic. 7:13-17.

Renaud, E.N.C., E.T.L. van Bueren, M.J. Paulo, F.A. van Eeuwijk, J.A. Juvik, M.G. Hutton, and J.R. Myers. 2014. Broccoli cultivar performance under organic and conventional management systems and implications for crop improvement. Crop Sci. 54:15391554, doi: 10.2135/cropsci2013.09.0596.

Sahamishirazi, S., J. Moehring, S. Zikeli, M. Fleck, W. Claupein, and S. Graeff-Hoenninger. 2018. Agronomic performance of new open pollinated experimental lines of broccoli (Brassica oleracea L. var. italica) evaluated under organic farming. PLoS One 13(5):e0196775, doi: 10.1371/journal.pone. 0196775.

Sánchez, E., T. Butzler, L. Stivers, R. Pollock, T. Elkner, S. Bogash, and W. Lamont. 2016. Performance of broccoli cultivars in spring and fall evaluations in Pennsylvania. HortTechnology 26:869-876, doi: 10.21273/HORTTECH03519-16.

Schumacher, B.R., J. O'Sullivan, A.W. McKouwn, R.A. Brammall, R. Baker, W.J. Bouw, L.A. Reynolds, and G.E. Banfield. 1988. Vegetable cultivar trials 1988. Res. Rpt. 99. Hort. Expt. Sta., Simcoe, ON, Canada.

Serban, D. and G. Nedelea. 2012. Research concerning the comparative analysis of the impact of different morphological features on yield in an assortment of broccoli. J. Hort. For. Biotechnol. 16:210-213.

Sterrett, S.B., K.G. Haynes, and C.P. Savage. 2004. Cluster analyses on quality attributes identify broccoli cultivars suitable for early and main-season harvests on the eastern shore of Virginia. HortTechnology 14:376-380, doi: 10.21273/HORTTECH.14.3.0376.

Talbot, A. 2017. Evaluating natural and induced resistance of broccoli (Brassica oleracea var. italica) against Pieris rapae. MS Thesis, Univ. Minnesota, Minneapolis.

Toth, N., J. Borosić, I. Zutić, B. Novak, and B. Benko. 2007. Yield components of broccoli cultivars grown in the continental climate of Croatia. Acta Hort. 729:255-260, doi: 10.17660/ActaHortic.2007.729.41.

Toth, N., S. Fabek, B. Benko, M. Herak Ćustić, and I. Radojčić Redovniković. 2014. Yield components and glucosinolate contents of broccoli cultivars in summer-autumn growing cycle. Acta Hort. 1040:323-329, doi: 10.17660/ActaHortic.2014.1040.45.

Wagner, P., G. Matheke, D. Dinkel, and M. Griffith. 1989. Summary of vegetable variety trials, Fairbanks, Alaska, 1978-1985. Univ. Alaska Fairbanks Circ. 67.

Walton, L.R. and J.H. Casada. 1988. Evaluation of broccoli varieties for mechanical harvesting. Appl. Eng. Agr. 4(1):5-7, doi: $10.13031 / 2013.26570$.

Wilcox, M. 1995. Broccoli variety trials 1994/1995. 10 July 2020. <http:// hdl.handle.net/10150/221445>.

Wilcox, M. 1996. Broccoli variety trials 1995/1996. 10 July 2020. <http://hdl.handle.net/10150/214722>.

Wright, S., D. Slone, and J. Snyder. 2015. Fall broccoli cultivar trial 2012-2013. Purdue Fruit Vegetable Res. Rpt. Paper 116. 10 July 2020. < https://docs.lib.purdue.edu/ fvtrials $/ 116>$.
Zerkoune, M.A. 2001. Field evaluation of broccoli varieties grown in southwest low desert soils. Coop. Ext., Univ. Arizona, Yuma, AZ. 10 July 2020. <http:// hdl.handle.net/10150/214933>.

\section{Cucumber}

2015. Eastern sustainable organic cucurbit project trial results: 2014 \& 2015 . Cornell Univ., Auburn Univ., Clemson Univ., North Carolina State Univ.

2016. Eastern sustainable organic cucurbit project trial results: 2016. Cornell Univ., Auburn Univ., Clemson Univ., North Carolina State Univ.

Abdel, C. 2009. Evaluating the productivity of five cucumber (Cucumis sativus L.) cultivars and their responses to varying rates of gibberellic acid (GA3). J. Dohuk Univ. Agr. Vet. 12(1):1-10.

Adesina, J.M. and A.T. Benjamin. 2016. Varietal productivity and planting date effect on the growth and yield of cucumber (Cucumis sativus L.) in Owo, south western Nigeria. Intl. J. Hortic. 6(23):1-9, doi: 10.5376/ijh.2016.06.0023.

Aviles-Rodriguez, L., E. Caraballo, and G. Fornaris-Rullan. 1990. An evaluation of 10 cucumber (Cucumis sativa L.) cultivars in southern Puerto Rico. J. Agr. Univ. P. R. 74:461-463, doi: 10.46429/jaupr.v74i4.6686.

Ballester, M.R., C.A.R. Caro, and J.V. Fortuno. 1960. An evaluation of pickling cucumber varieties at Isabela Substation. J. Agr. Univ. P. R. 46:360-362, doi: 10.46429/ jaupr.v46i4.12356.

Bergefurd, B.R., T. Harker, and D.S. Wright. 2003. Evaluation of cucumber cultivars for southern Ohio, 2003. Ohio State Univ., Piketon.

Bidein, T., N.E.S. Lale, and U. Zakka. 2016. Efficacy of combining varietal resistance with organic fertilizer application in reducing infestation of cucumber (Cucumis sativus L.) by insect pests in the Niger Delta. Amer.-Eurasian J. Agr. Environ. Sci. 16:532-542, doi: 10.5829/idosi.aejaes.2016.16.3.12868.

Blazquez, C.H. 1970. Varietal resistance to three cucumber foliar diseases in southwest Florida. Plant Dis. Rep. 54:52-55.

Boches, P., D. Kean, P. Kusolwa, J. Myers, and J. Stang. 2006. Vegetable variety trials 2005. Oregon State Univ., Corvallis.

Bogash, S. 2013. Green slicer cucumber variety trial year 2. Cumberland County Coop. Ext., Carlisle, PA.

Brown, R. 2011. 2010 Vegetable variety trial report. 6 July $2020 .<$ http://digital commons.uri.edu/riaes_bulletin/13>.

Brown, R. 2013. Cucumber variety trials 2012. 6 July 2020. <http://digitalcommons. uri.edu/riaes_bulletin/5>. 
Call, A. 2010. Studies on resistance to downy mildew in cucumber (Cucumis sativus L.) caused by Pseudoperonospora cubensis. MS Thesis, North Carolina State Univ., Raleigh.

Call, A. 2012. Inheritance of resistance to downy mildew in cucumber (Cucumis sativus L.) PI 197088 and effect of interaction of host plant resistance, fungicides, and environment on severity of downy mildew on cucumber. PhD Diss., North Carolina State Univ., Raleigh.

Call, A.D., A.D. Criswell, T.C. Wehner, K. Ando, and R. Grumet. 2012. Resistance of cucumber cultivars to a new strain of cucurbit downy mildew. HortScience 47:171-178, doi: 10.21273/HORTSCI.47.2.171.

Cerne, M., M. Skof, and K. Ugrinovic. 2000. Pickling cucumber (Cucumis sativus L.) cultivars grown in two different ecological conditions. Acta Hort. 533:549-555, doi: 10.17660/ActaHortic.2000.533.69.

Coolong, T. 2015. 2014/2015 Vegetable crop variety trial and research report. Univ. Georgia Ext., Tifton.

Cooper, J.G. 2012. Cucurbit downy mildew (Pseudoperonospora cubensis): Cucumber resistance. MS Thesis, Virginia Polytechnic Inst. State Univ., Blacksburg.

Crespo, G.M. 1980. Pickling cucumber (Cucumis sativus L.) cultivar evaluation in northwestern Puerto Rico. J. Agr. Univ. P. R. 66:177-180.

Dawson, J. 2017. 2017 Cucumber variety trial report. 6 July 2020. < https://seedtokitchen. horticulture.wisc.edu/trial-results.html $>$.

Dawson, J. 2018. 2018 Cucumber variety trial report. 6 July 2020. <https://seedtokitchen. horticulture.wisc.edu/trial-results.html $>$.

Dawson, J. 2019. 2019 Cucumber variety trial report. 6 July 2020. <https://seedtokitchen.horticulture.wisc.edu/trial-results.html $>$.

Echavez-Badel, R. 1989. Performance of cucumber varieties in soil infested with root-knot and reniform nematodes. J. Agr. Univ. P. R. 73:321-325.

Eifediyi, E.K. and S.U. Remison. 2009. Effect of time of planting on the growth and yield of five varieties of cucumber (Cucumis sativus L.). Rep. Opinion 1(5):81-90.

Ene, C.O., P.E. Ogbonna, C.U. Agbo, and U.P. Chukwudi. 2016. Evaluation of sixteen cucumber (Cucumis sativus L.) genotypes in derived savannah environment using path coefficient analysis. Not. Sci. Biol. 8:85-92, doi: $10.15835 / \mathrm{nsb} .8 .1 .9722$.

Ernest, E. 2009. Slicing cucumber variety trial results 2009. Univ. of Delaware Res. Educ. Ctr., Georgetown.

Frost, E. 2014. Central VA organic cucurbit variety trial, Summer 2014. 6 July 2020. $<$ https://www.carolinafarmstewards.org/wp-
content/uploads/2015/02/Central-VA-OrganicCurcurbit-Variety-Trials-FINAL.pdf $>$.

George, C. 1972. Evaluation of slicing cucumber varieties at Union Agricultural Station Saint Lucia. Proc. X Annu. Mtg. Caribbean Food Crops Soc., San Juan, Puerto Rico, 11-16 June 1972, doi: 10.22004/ag.econ.263333.

Ghallab, M., N. Habashi, and A. Iskandar. 2011. Sensitivity of four cucumber cultivars to some piercing sap sucking pests infestation and their impact on yield. Egyptian J. Agr. Res. 89:1363-1373.

Goldy, R. 2011. Evaluation of seven slicing cucumbers in southwest Michigan. Michigan State Univ., Benton Harbor.

Goldy, R. and K. Farrantella. 2017. Slicing cucumber performance in southwest Michigan. Southwest Michigan Res. Ext. Ctr., Benton Harbor.

Goldy, R. and V. Wendzel. 2015. Evaluation of 13 slicing cucumbers in southwest Michigan. Southwest Michigan Res. Ext. Ctr., Benton Harbor.

Goldy, R., V. Wendzel, and D. Francis. 2001. Bejo pickle trial. Southwest Michigan Res. Ext. Ctr., Benton Harbor.

Gruetze, S., K. Oxley, and C. Rivard. 2016. 2016 Evaluation of standard pickling cucumber varieties in Kansas. Kansas State Univ., Manhattan.

Guan, W. 2016. 2016 Cucumber variety evaluation in a high tunnel at southwest Indiana. Vegetable Crops Hotline Issue 622.

Guan, W., E.T. Maynard, B. Aly, J. Zakes, D.S. Egel, and L.L. Ingwell. 2019. Parthenocarpic cucumber cultivar evaluation in high-tunnel production. HortTechnology 29:634-642, doi: 10.21273/HORTTECH04 370-19.

Hassell, R., C. Wallace, and K. Scaife. 1996. Pickling cucumber cultivar evaluation trials. Ohio Agr. Res. Dev. Ctr., Wooster.

Holdsworth, W.L., C.F. Summers, M. Glos, C.D. Smart, and M. Mazourek. 2014. Development of downy mildew-resistant cucumbers for late-season production in the northeastern United States. HortScience 49:10-17, doi: 10.21273/HORTSCI.49.1.10.

Hutton, M. and D. Handley. 2009. Evaluation of pickling and slicing cucumber varieties. Univ. Maine Coop. Ext., Monmouth.

Ikenganyia, E., U. Ndubuaku, C. Onyeonagu, and I. Dimelu. 2015. Performance of three varieties of cucumber (Cucumis sativus) in composted rice husks plus poultry manure media and the effects on soil nutrient status. Intl. J. Plant Soil Sci. 5(3):167-174, doi: 10.9734/IJPSS/2015/13603.

Ingratta, F.J. and W.A. Straver. 1978. Vegetable cultivar trials 1978. Ontario Ministry Agr. Food, Vineland Sta., ON, Canada.
Jett, L.W. 2011. Parthenocarpic cucumbers are a successful double crop for high tunnels. West Virginia Univ., Morgantown.

Jett, L.W. and J. Quinn. 2005. Growing cucumbers within a high tunnel. Univ. Missouri, Columbia.

Johnson, G. and E. Ernest. 2010. Small plot pickling cucumber variety trial and pickling cucumber evaluations for traits affecting mechanical harvest. Univ. Delaware Res. Educ. Ctr., Georgetown.

Kaaan, F. and G. Anais. 1971. A comparative trial of cucumber varieties and hybrids in Guadeloupe 1980. Proc. IX Annu. Mtg. Caribbean Food Crops Soc., Georgetown, Guyana. DOI: 10.22004/ag.econ.263361.

Kean, D., J. Myers, and J. Stang. 2004. Vegetable variety trials 2003. Oregon State Univ. Ext., Corvallis.

Kee, E. and E. Ernest. 2005. 2005 University of Delaware pickle variety trials. Univ. Delaware Res. Educ. Ctr., Georgetown.

Kee, E. and E. Ernest. 2007. 2007 University of Delaware pickle variety trial. Univ. Delaware Res. Educ. Ctr., Georgetown.

Kee, E., T. Wootten, and K. Bros. 2002. 2002 University of Delaware spring pickle variety trial. Univ. Delaware Res. Educ. Ctr., Georgetown.

Kee, E., T. Wootten, and C. Farm. 2002. 2002 University of Delaware fall pickle variety trial. Univ. Delaware Res. Educ. Ctr., Georgetown.

Khan, B., L. Wells, B. Bostian, and C. Maness. 2002. Cucumber variety trial. Oklahoma State Univ., Stillwater.

Khan, Z.A., A.H. Shah, R. Gul, A. Majid, U. Khan, and H.A.B. Ahmad. 2015. Morpho-agronomic characterization of cucumber germplasm for yield and yield associated traits. Intl. J. Agron. Agr. Res. 6(1):1-6.

Kretchman, D.W., M. Jameson, C. Willer, and M. Bennet. 1990. Cultivar trials for northwestern Ohio. Ohio Agric. Res. Dev. Ctr., Wooster.

Kretchman, D.W. and M.A. Jameson. 1981. Pickling cucumber cultivar evaluation trials - 1980. Ohio Agric. Res. Dev. Ctr., Wooster.

Kretchman, D.W., M.A. Jameson, and C.C. Willer. 1982. Cucumber cultivar evaluation trials. Ohio Agric. Res. Dev. Ctr., Wooster, OH.

Law-Ogbomo, K.E. and S.A. Ogedegbe. 2019. Effect of oil palm refuse bunch ash on the growth and yield of cucumber (Cucumis sativus L.) varieties in humid ultisols pedoenvironment. Trop. Subtrop. Agroecosystems 22(2):249-256.

López, A.P. and R.M. Barbosa. 1964. Yields of four cucumber varieties after 
treatment with a nematicide. J. Agric. Univ. P. R. 48:135-139, doi: 10.46429/ jaupr.v48i2.12984.

Loughton, A., J. O'Sullivan, A.W. McKouwn, R.A. Brammall, R. Baker, W.J. Bouw, J. Packer, and G.E. Banfield. 1993. Vegetable cultivar trials 1992. Hortic. Expt. Sta., Simcoe, ON, Canada.

Matheke, G.E.M., K. DiCristina, E. Gardiner, P.S. Holloway, J. Fredrickson, E. Hatch, W. Hoefler, E. Matthiews, D. Norris, S. Pearce, P.P. Sartz, and S. Snater. 2010. Annual vegetable trials 2009. Univ. Alaska, Fairbanks.

Matheke, G.E.M., J. Hanscom, P.S. Holloway, and A. Gardiner. 2003. Vegetable trials 2003. Univ. Alaska, Fairbanks.

Matheke, G.E.M., J. Hanscom, P.S. Holloway, and E. Gardiner. 2006. Vegetable trials 2006. Univ. of Alaska, Fairbanks.

McGrath, M., G. Fox, and S. Menasha. 2009. Downy mildew susceptibility of cucumber varieties, New York 2008. Cornell Univ., Riverhead, NY.

Nandwani, D., J. Williamson, and V. Forbes. 2014. Cucumber cultivar study in the U.S. Virgin Islands 2014. Proc. L Annu. Mtg. Caribbean Food Crops Soc., St. Thomas, U.S. Virgin Islands, 7-11 July 2014. doi:10.22004/ag.econ.253335.

Nwofia, G.E., A.N. Amajuoyi, and E.U. Mbah. 2015. Response of three cucumber varieties (Cucumis sativus L.) to planting season and NPK fertilizer rates in lowland humid tropics: Sex expression, yield and inter-relationships between yield and associated traits. Intl. J. Agr. For. 5(1):30-37, doi: 10.5923/ j.ijaf.20150501.05.

O'Sullivan, J. and W.J. Bouw. 1992. Pickling cucumber melon - pepper. Ontario Ministry Agr. Food, Simcoe, ON, Canada.

O'Sullivan, J. and W.J. Bouw. 1995. Pickling cucumber musk melon pepper beet. Ontario Ministry Agr. Food, Simcoe, ON, Canada.

O'Sullivan, J., W.J. Bouw, and W.T. Sturkenboom. 1982. Ontario pickling cucumber \& pepper cultivar trials. Ontario Ministry Agr. Food, Simcoe, ON, Canada.

O’Sullivan, J., S. Lonsbary, and R. Grohs. 2001. Vegetable production research report 2001. Univ. Guelph, Simcoe, ON, Canada.

O'Sullivan, J., L. Reynolds, and W.J. Bouw. 1980. Ontario pickling cucumber cultivar trials - 1980. Ontario Ministry Agr. Food, Simcoe, ON, Canada.

Oregon State University. 2010. Pickling cucumber variety and weed control trials (1992). 6 July 2020. <https://agsci.oregon state.edu/oregon-vegetables/pickling-cucumber-variety-and-weed-control-trials-1992>.
Organic Seed Alliance. 2012. 2012 California organic variety trial report. Organic Seed Alliance, Port Townsend, WA.

Palada, M.C. and J.M.M. Agricultural. 2004. On-farm evaluation of cucumber cultivars for summer production in the U.S. Virgin Islands. Proc. Caribbean Food Crops Soc. 40:16-21.

Pessala, R. 1987. Cultivation of parthenocarpic pickling cucumber varieties in a plastic house. Annales Agriculturae Fenniae 26:299-306.

Philips, B. 2014. 2014 Pickling cucumber variety trial. Michigan State Univ. Ext., Saginaw.

Philips, B. 2015. Michigan State University 2015 Seedless pickling cucumber variety trial. Michigan State Univ. Ext., Saginaw.

Philips, B. 2016. MSU 2016 Seedless pickling cucumber variety trial. Michigan State Univ. Ext., Saginaw.

Phillips, B. 2017. 2017 Seedless pickling cucumber variety trial. Michigan State Univ. Ext., Saginaw.

Phillips, B. 2018. 2018 Seedless pickling cucumber variety trial. Michigan State Univ. Ext., Saginaw.

Phillips, B. 2020. 2019 Seedless pickling cucumber variety trial. Michigan State Univ. Ext., Saginaw.

Sakata, Y., M. Sugiyama, and Y. Yoshioka. 2010. Morphological characteristics and yield of five major cucumber types under cultivation in Japan. Bul. Natl. Inst. Veg. Tea Sci. 9:113-123.

Sánchez, E., W.J. Lamont, and M.D. Orzolek. 2008. Newspaper mulches for suppressing weeds for organic high-tunnel cucumber production. HortTechnology 18:154-157, doi: 10.21273/HORTTECH.18.1.154.

Satanek, A., B. Rowell, D. Slone, and J.C. Snyder. 2003. Yields and gross returns from new slicing cucumber varieties. Univ. Kentucky, Lexington.

Schumacher, B.R., J. O'Sullivan, A.W. McKouwn, R.A. Brammall, R. Baker, W.J. Bouw, L.A. Reynolds, and G.E. Banfield. 1988. Vegetable cultivar trials 1988. Hortic. Expt. Sta., Simcoe, ON, Canada.

Shetty, N. and T. Wehner. 1998. Evaluation of oriental trellis cucumbers for production in North Carolina. HortScience 33:891-896, doi: 10.21273/HORTSCI.33.5.891.

Shetty, N.V. and T.C. Wehner. 2002. Screening the cucumber germplasm collection for fruit yield and quality. Crop Sci. 42: 2174-2183, doi: 10.2135/cropsci2002.2174.

Shrefler, J., M. Taylor, M. Anderson, and R. DeWitt. 2014. Cucumber fall planting demonstration. Oklahoma State Univ., Stillwater.
Sideman, B. 2011. Greenhouse cucumber variety trial, 2010. Univ. New Hampshire Coop. Ext. Durham.

Simonne, E., E. Carden, and A. Caylor. 1996. 'General Lee' among top marketable yielders in slicer cucumber trial for third year. Auburn Univ. Prog. Rep. 130.

Swallow, W.H. and T.C. Wehner. 1989. Optimum allocation of plots to years, seasons, locations, and replications, and its application to once-over-harvest cucumber trials. Euphytica 43:59-68, doi: 10.1007/BF00037897.

Wagner, P., G. Matheke, D. Dinkel, and M. Griffith. 1989. Summary of vegetable variety trials, Fairbanks, Alaska, 1978-1985. Univ. Alaska Fairbanks, Fairbanks.

Wehner, T. 1988. Effect of end-border condition on small-plot yield of cucumber. Euphytica 38:113-119.

Wehner, T.C., N.V. Shetty, and R.L. Clark. 2000. Screening the cucumber germplasm collection for combining ability for yield. HortScience 35:1141-1150, doi: 10.21273/HORTSCI.35.6.1141.

\section{Pepper}

Aly, B. 2003. 2003 On-farm pepper cultivar trial. Univ. Illinois, Simpson.

Aly, B. 2004. 2004 Pepper cultivar trial for southern Illinois. Univ. Illinois, Simpson.

Aly, B. and J.D. Kindhart. 2005. 2005 Pepper cultivar trial. Univ. Illinois, Simpson.

Aly, B. and J.D. Kindhart. 2006. 2006 DSAC Pepper variety trial. Univ. Illinois, Simpson.

Aly, B. and J.D. Kindhart. 2007. 2007 DSAC Pepper variety trial. Univ. Illinois, Simpson.

Appireddy, G.K., S. Saha, B.L. Mina, S. Kundu, G. Selvakumar, and H.S. Gupta. 2008. Effect of organic manures and integrated nutrient management on yield potential of bell pepper (Capsicum annuum) varieties and on soil properties. Arch. Agron. Soil Sci. 54:127-137, doi: 10.1080/03650340701836808.

Babadoost, M. 2009. Bell pepper evaluation for resistance to phytophthora blight (Phytophthora capsici). Univ. Illinois Urbana-Champaign, Urbana.

Babadoost, M. and A. Jurgens. 2008. Evaluation of bell peppers for resistance to phytophthora blight (Phytophthora capsici). Univ. Illinois Urbana-Champaign, Urbana.

Balkwill, W.R. 1997. 1997 Fresh market vegetable research report. 20 July 2020. < http://hdl.handle.net/10214/1891>.

Beck, J., A. Moore, and S. Gu. 2014. Central NC organic bell and hot pepper variety trial, Summer 2014. 20 July 2020. < https:// varietytrials.eorganic.info/sites/eorg-variety7/ 
files/1-Central-NC-Bell-and-Hot-PepperVariety-Trial-FINAL.pdf $>$.

Bergefurd, B.R., W. Lewis, T. Harker, L. Miller, A. Welch, and E. Weaks. 2011. Bell pepper cultivar performance trial grown in southern Ohio - 2011. Ohio State Univ., Piketon.

Boches, P., D. Kean, P. Kusolwa, J. Myers, and J. Stang. 2006. Vegetable variety trials 2005. 20 July 2020. < https:// ir.library.oregonstate.edu/concern/open_educational_resources/t435gd25v $>$.

Bogash, S. and T. Elkner. 2011. Colored bell pepper high tunnel variety trial 2011. Franklin County Coop. Ext., Chambersburg, PA; Lancaster County Coop. Ext., Lancaster, PA.

Boyhan, G., T. Coolong, and C. McGregor. 2015. Evaluation of pepper varieties for production in Georgia. Univ. Georgia, Tifton.

Boyhan, G.E., C. McGregor, S. O'Connell, J. Biang, and D. Berle. 2020. A comparison of 13 sweet pepper varieties under an organic farming system. HortTechnology 30:135-143, doi: 10.21273/HORTTECH04455-19.

Brown, R. 2014. No 22013 Pepper variety trial. Rhode Island Agr. Exp. Sta. Bull. Paper 8. 20 July 2020. < http://digitalcommons.uri. edu/riaes_bulletin/8 $>$.

Butler, M.D. and N.F. Oebker. 1986. Pepper variety trials, Yuma 1986. 20 July 2020. $<$ http://hdl.handle.net/10150/221238>.

Colucci, S., C. Gunter, and M. Hannah. 2012. Colored bell pepper variety trial. Fall 2011 Commercial Fruit and Vegetable Variety Trials. Auburn Univ. Reg. Bull. 25.

Coolong, T. 2017. Trial report: Bell pepper variety evaluation Spring 2017. 20 July 2020. <https://vegetables.caes.uga.edu/trialresults/bell-pepper.html $>$.

Damicone, J., B. Anaya, R. Dees, and B. King. 2018. Disease and yield response of pepper cultivars. Oklahoma State Univ., Stillwater.

Dawson, J. 2015. 2015 Bell pepper variety trial report. 20 July 2020. <https://seedtokitchen.horticulture.wisc.edu/trial-results.html $>$.

Dawson, J. 2016. 2016 Bell pepper variety trial report. 20 July 2020. $<$ https://seedtokitchen.horticulture.wisc.edu/trial-results.html $>$.

Dhanvantari, B.N. 1993. Studies on bacterial spot of sweet pepper. Agr. Can. Res. Sta., Harrow, ON, Canada.

Dunn, A.R., H.W. Lange, and C.D. Smart. 2014. Evaluation of commercial bell pepper cultivars for resistance to phytophthora blight (Phytophthora capsici). Plant Health Prog. 15:19-24, doi: 10.1094/PHP-RS-13-0114.

Dunn, A.R., L.E. Wyatt, M. Mazourek, S. Reiners, and C.D. Smart. 2013. Performance and tolerance to phytophthora blight of bell pepper varieties. HortTechnology 23:382390, doi: 10.21273/HORTTECH.23.3.382.

Escudero, J. 1987. Yield and tolerance of bell pepper (Capsicum annuum L.) cultivars to potato virus y isolate from Puerto Rico. J. Agric. Univ. P. R. 71:337-340, doi: 10.46429/jaupr.v71i3.6978.

Fajinmi, A.A., A. Omotayo, C. Ribeiro, A.K. Oluleye, and O.B. Fajinmi. 2018. Evaluation of pepper genotypes for disease tolerance in southwest Nigeria. Acta Hort. (1225):457-464, doi: 10.17660/ActaHortic.2018.1225.65.

Fouche, B., D. Boelk, B. Mullen, S. Whiteley, D. Colbert, and R. Wittie. 2006. 2006 Bell pepper variety evaluation trials. Univ. California Coop. Ext., Stockton.

Gahler, A. and M. Hofelich. 2015. Northern Ohio pepper variety trial - 2014. Purdue Fruit and Vegetable Res. Rpt. Paper 107. 20 July 2020. <https://docs.lib.purdue.edu/ fvtrials/107>.

Gahler, A.M. and M. Hofelich. 2017. Northern Ohio pepper variety trial - 2017. Ohio Agricultural Res. Dev. Ctr., Fremont.

Garton, R.W. and W.R. Balkwill. 1994. Fresh market vegetable research report. 20 July 2020. < http://hdl.handle.net/10214/ $7313>$.

Gillier Eagen, B. and R. Wright. 1988. 1988 Vegetable trial report. 20 July 2020. $<$ http://hdl.handle.net/10214/5388>.

Goldy, R. 2007. Evaluation of twelve pepper cultivars in southwest Michigan. Southwest Michigan Res. Ext. Ctr., Benton Harbor.

Goldy, R. 2010. Evaluation of 14 bell pepper cultivars in southwest Michigan. Southwest Michigan Res. Ext. Ctr., Benton Harbor.

Goldy, R. 2013. Evaluation of 15 bell pepper cultivars in southwest Michigan. Southwest Michigan Res. Ext. Ctr., Benton Harbor.

Goldy, R. 2016. Evaluation of 11 bell pepper cultivars in southwest Michigan. Southwest Michigan Res. Ext. Ctr., Benton Harbor.

Goldy, R. and V. Wendzel. 2004. Performance of 15 bell pepper selections in southwest Michigan. Southwest Michigan Res. Ext. Ctr., Benton Harbor.

Goldy, R. and V. Wendzel. 2012. Evaluation of 16 Phytophthora capsici-tolerant pepper cultivars in southwest Michigan. Southwest Michigan Res. Ext. Ctr., Benton Harbor.

Goldy, R., V. Wendzel, and D. Francis. 2001. Response of three pepper cultivars to gibberellic acid. Southwest Michigan Res. Ext. Ctr., Benton Harbor.

Grassbaugh, E., M. Hofelich, and M. Koenig. 2010. New crop pepper germplasm evaluation for northwest Ohio, 2010. Ohio State Univ., Columbus.
Grassbaugh, E., M. Hofelich, and M. Koenig. 2011. New crop pepper germplasm evaluation for northwest Ohio, 2011. Ohio State Univ., Columbus.

Greenland, R., L. Besemann, and D. Anderson. 2001. Pepper hybrid performance trial. 20 July 2020. <https://www.ag.ndsu.edu/oakes/2001Report/pppt01.htm>.

Holloway, P.S., J. Hanscom, E. Gardiner, and G.E.M. Matheke. 2008. Vegetable trials 2008. 20 July 2020. <http://hdl.handle.net/ $11122 / 2824>$.

Hutton, M. and D. Handley. 2007. Bell pepper cultivar performance under short, variable growing seasons. HortTechnology 17: 136-141, doi: 10.21273/HORTTECH.17. 1.136 .

Hutton, M. and D. Handley. 2015. Evaluation of sweet pepper varieties, 2014. 20 July 2020. <https:/extension.umaine.edu/ highmoor/research/evaluation-of-sweetpepper-varieties-2014/>.

Hutton, M.G., D. Handley, T. Jackson, and C. Howard. 2003. The pick of the crop Highmoor Farm pepper variety trial. Univ. Maine Coop. Ext., Monmouth.

Jones, R.T., C.T. Back, and J.C. Snyder. 2004. Bell and jalapeño pepper evaluations for yield and quality in eastern Kentucky. Univ. Kentucky, Quicksand.

Jones, R.T., A.F. Sears, and J.C. Snyder. 2005. Bell pepper evaluations for yield and quality in eastern Kentucky. Univ. Kentucky, Quicksand.

Juroszek, P. and H.-H. Tsai. 2009. Yields of organically grown sweet pepper cultivars and lines during the hot-wet and cool-dry season in the tropics. HortTechnology 19:418422, doi: 10.21273/HORTSCI.19.2.418.

Kean, D., J. Myers, and J. Stang. 2004. Vegetable variety trials 2003. Oregon State Univ. Ext., Corvallis.

Kemble, J., E. Vinson, R. Akridge, and A. Caylor. 2013. Bell pepper trials in north and south Alabama. Variety trials Spring 2013. Auburn Univ., Reg. Bull. 29.

Khan, B., L. Wells, B. Bostian, and C. Maness. 2002. Bell pepper variety trial. Oklahoma State Univ., Stillwater.

Khan, B. and D. Williams. 2014. Summer 2013 Bell pepper variety trial. Oklahoma State Univ., Stillwater.

Kindhart, J.D., B. Aly, and E. Wahle. 2009. 2009 DSAC pepper variety trial. Univ. Illinois, Simpson.

Kline, W. and A. Wyenandt. 2019. Bell pepper bacterial leaf spot resistance cultivar trial results in New Jersey - 2019. Rutgers Univ., Millville, NJ; Bridgeton, NJ.

Koner, S., R. Chatterjee, and S. Datta. 2015. Effect of planting dates and varieties on growth, fruit yield and quality of 
bell pepper (Capsicum annuum L.). J. Appl. Nat. Sci. 7:734-738, doi: 10.31018/ jans.v7i2.675.

Kousik, C.S. and D.F. Ritchie. 1998. Response of bell pepper cultivars to bacterial spot pathogen races that individually overcome major resistance genes. Plant Dis. 82:181-186, doi: 10.1094/PDIS.1998.82.2.181.

Krasnow, C.S., A.A. Wyenandt, W.L. Kline, J.B. Carey, and M.K. Hausbeck. 2017. Evaluation of pepper root rot resistance in an integrated phytophthora blight management program. HortTechnology 27:408-415, doi: 10.21273/HORTTECH03697-17.

Kretchman, D.W., M. Jameson, C. Willer, and M. Bennet. 1990. Cultivar trials for northwestern Ohio. Ohio Agricultural Res. Dev. Ctr., Wooster.

Kundu, P., A. Mukherjee, and N.C. Sahu. 2018. Suitable cultivars of broccoli, red cabbage, capsicum and french bean for alluvial tracts of West Bengal. J. Krishi Vigyan 7:197-202, doi: 10.5958/ 2349-4433.2018.00132.0.

Langenhoven, P. 2018. Colored sweet pepper cultivar evaluation for high tunnel production in west-central Indiana, 2018. Purdue Fruit Veg. Res. Rpt. Paper 185. 20 July $2020<$ https://docs.lib.purdue.edu/ fvtrials $/ 185>$.

Lawson, V. 2005. Bell pepper cultivar trial - 2005. Iowa State Univ. Res. Demonstration Farms Prog. Rpt. 2005.

Lawson, V. and H. Taber. 2004. Bell pepper cultivar trial - 2004. Iowa State Univ., Fruitland.

Lewis Ivey, M.L., C. Nava-Diaz, and S.A. Miller. 2004. Identification and management of Colletotrichum acutatum on immature bell peppers. Plant Dis. 88:1198-1204, doi: 10.1094/PDIS.2004.88.11.1198.

Loughton, A. and R. Baker. 1975. Vegetable variety trials 1975. Hort. Expt. Sta., Simcoe, ON, Canada.

Loughton, A., J. O'Sullivan, A.W. McKouwn, R.A. Brammall, R. Baker, W.J. Bouw, J. Packer, and G.E. Banfield. 1993. Vegetable cultivar trials 1992. Hortic. Expt. Sta., Simcoe, ON, Canada.

Matheke, G.E.M., K. DiCristina, E. Gardiner, P.S. Holloway, J. Fredrickson, E. Hatch, W. Hoefler, E. Matthiews, D. Norris, S. Pearce, P.P. Sartz, and S. Snater. 2010. Annual vegetable trials 2009. 20 July 2020. $<$ http://hdl.handle.net/11122/2826>.

Matheke, G.E.M., J. Hanscom, P.S. Holloway, and A. Gardiner. 2003. Vegetable trials 2003. 20 July 2020. < http:// hdl.handle.net/11122/2114>.

Matheke, G.E.M., J. Hanscom, P.S. Holloway, and E. Gardiner. 2006. Vegetable trials
2006. 20 July 2020. < http://hdl.handle.net/ $11122 / 2818>$.

Maynard, E.T. 2005. Bell pepper cultivar evaluation, northern Indiana, 2004. Purdue Fruit Veg. Res. Rpt. Paper 24. 20 July 2020. <https://docs.lib.purdue.edu/ fvtrials $/ 24>$.

Maynard, E.T. 2006. Bell pepper cultivar evaluation, northern Indiana, 2005. Purdue Fruit Veg. Res. Rpt. Paper 17. 20 July 2020. <https://docs.lib.purdue.edu/ fvtrials $/ 17>$.

Mazourek, M., G. Moriarty, M. Glos, M. Fink, M. Kreitinger, E. Henderson, G. Palmer, A. Chickering, D.L. Rumore, D. Kean, J.R. Myers, J.F. Murphy, C. Kramer, and M. Jahn. 2009. 'Peacework': A cucumber mosaic virus-resistant early red bell pepper for organic systems. HortScience 44:1464-1467, doi: 10.21273/ HORTSCI.44.5.1464.

McAvoy, G., D. Sui, R. Raid, and M. Ozores-Hampton. 2010. Bacterial spot resistant pepper trials in Florida. Proc. Florida State Hortic. Soc. 123:160-164.

Miller, C., G. McAvoy, R. Raid, and M. Ozores-Hampton. 2016. Cultivar assessment for bacteria spot of pepper resistance in south Florida. Univ. Florida/ IFAS Palm Beach County Ext.

Muehmer, J., B. Gillier Eagen, and R. Wright. 1985. Vegetable trial report. Ridgetown College, Ridgetown, ON, Canada.

Muehmer, J., B. Gillier Eagen, and R. Wright. 1987. Vegetable trial report. Ridgetown College, Ridgetown, ON, Canada.

Muehmer, J.K. 1970. Pickling pepper performance trials - 1970. Ridgetown College, Ridgetown, ON, Canada.

Mullen, B., S. Whiteley, D. Colbert, and N. Prichard. 2003. 2003 Bell pepper variety evaluation trials. Univ. California Coop. Ext., Stockton.

Nandwani, D. 2012. Growth and yield response of sweet pepper cultivars in the US Virgin Islands 2012. Proc. XLVIII Annu. Mtg. Caribbean Food Crops Soc., Playa del Carmen, Mexico, 20-26 May 2012, doi: 10.22004/ag.econ. 253717.

Northern Organic Vegetable Improvement Collaborative. 2019. 2019 NOVIC III Bell pepper trial. 20 July 2020 . < https://varietytrials.eorganic.info/node/811 $>$.

O'Sullivan, J. and W.J. Bouw. 1992. Pickling cucumber melon - pepper. Ontario Ministry Agr. Food, Simcoe, ON, Canada.

O’Sullivan, J., S. Lonsbary, and R. Grohs. 2001. Vegetable production research report 2001. Univ. Guelph, Simcoe, ON, Canada.

Oxley, K., D. Loewen, and C. Rivard. 2016. 2016 Evaluation of hybrid bell pepper varieties for high tunnel production in
Kansas. Purdue Fruit Veg. Res. Rpt. Paper 163. 20 July 2020. <https://docs.lib. purdue.edu/fvtrials/163 $>$.

Oxley, K. and C. Rivard. 2015. 2014 Evaluation of hybrid bell pepper varieties for high tunnel production in Kansas. Kansas State Univ. Manhattan.

Oxley, K. and C. Rivard. 2017. 2017 Evaluation of hybrid bell pepper varieties for high tunnel production in Kansas. Kansas State Univ. Manhattan.

Parada-Rojas, C.H. and L.M. QuesadaOcampo. 2019. Characterizing sources of resistance to phytophthora blight of pepper caused by Phytophthora capsici in North Carolina. Plant Health Prog. 20:112-119, doi: 10.1094/PHP-09-18-0054-RS.

Parmenter, D., R.L. Nagata, K. Pernezny, E. McAvoy, and K. Cushman. 2005. Evaluation of 25 entries of race 3 bacterial spot resistant bell peppers. Proc. Florida State Hortic. Soc. 118:142-145.

Pisarczyk, J.M. and C.C. Willer. 1982. Pepper cultivar trials-1981. Ohio Agricultural Res. Dev. Ctr., Fremont.

Pitblado, R.E. 2000. Insect and disease management trials. Ridgetown College, Ridgetown, ON, Canada.

Pitblado, R.E. and A.W. Schaafsma. 1989. Fungicide and insecticide trials 1989. Ridgetown College, Ridgetown, ON, Canada.

Precheur, B., R. Callendar, and H. Perez. 2012. 2012 Green pepper cultivar evaluation. Ohio State Univ., Celeryville.

Precheur, B., R. Callendar, H. Perez, and J. Reyes. 2009. 2009 Green pepper cultivar evaluation. Ohio State Univ., Celeryville.

Rangarajan, A. and M. McGrath. 2001. Evaluation of pepper cultivars for tolerance to Phytophthora capsici and impact of messenger on tolerance and yield. 20 July 2020. $<$ https://hdl.handle.net/1813/46259>.

Reid, J., K. Klotzbach, and N. Hoover. 2011. High tunnel pepper variety trial, 2011. Cornell Univ., Ithaca, NY.

Rivard, C., K. Oxley, M. Gawron, and M. Kennelly. 2013. Evaluation of hybrid bell pepper varieties for high tunnel production in Kansas. Kansas State Univ., Manhattan.

Rowell, B., R.T. Jones, W. Nesmith, A. Satanek, and J.C. Snyder. 2001. Bacterial spot resistance, yield, and quality of bell and specialty peppers. HortTechnology 11:648-657, doi: 10.21273/HORTTECH.11.4.648.

Rowell, B., R.T. Jones, W. Nesmith, and J.C. Snyder. 1999. Comparison of resistant cultivars for management of bacterial spot in peppers. HortTechnology 9:645-655, doi: 10.21273/HORTTECH.9.4.645.

Rowell, B., A. Satanek, and J.C. Snyder. 2004. Bell and jalapeño pepper 
evaluations for yield and quality in central Kentucky. Univ. Kentucky, Lexington.

Rowell, B., A. Satanek, and J.C. Snyder. 2005. Bell pepper cultivar evaluations for yield and quality in central Kentucky. Univ. Kentucky, Lexington.

Rowell, B. and J.C. Snyder. 2002. Bell and specialty pepper evaluations for bacterial spot resistance, yield, and quality. Univ. Kentucky, Lexington.

Saha, S.K. and L. Hanks. 2015. Kentucky bell pepper variety trial - 2014. In: Midwest Vegetable Trial Report for 2014. Purdue Univ., West Lafayette, IN.

Sanchez, E. 2012. 2012 Bell pepper variety trial. 20 July $2020 .<$ https://extension. psu.edu/2012-bell-pepper-variety-trial $>$.

Sánchez, E.S., T.M. Butzler, S.M. Bogash, T.E. Elkner, R.E. Oesterling, M.D. Orzolek, and L.J. Stivers. 2011. Pennsylvania statewide bell pepper cultivar evaluation. HortTechnology 21:384-390, doi: 10.21273/ HORTTECH.21.3.384.

Sánchez-Chávez, E., H.V. Silva-Rojas, G. Leyva-Mir, F. Villarreal-Guerrero, J.A. Jiménez-Castro, E. Molina-Gayosso, A.A. Gardea-Béjar, and G.D. Ávila-Quezada. 2017. An effective strategy to reduce the incidence of phytophthora root and crown rot in bell pepper. Interciencia 42:229-235.

Schumacher, B.R., J. O'Sullivan, A.W. McKouwn, R.A. Brammall, R. Baker, W.J. Bouw, L.A. Reynolds, and G.E. Banfield. 1988. Vegetable cultivar trials 1988. Hortic. Expt. Sta., Simcoe, ON, Canada.

Shoemaker, W. 2004. 2004 Bell pepper cultivar observation. Univ. Illinois, St. Charles.

Sideman, R.G. 2020. Colored bell pepper yields from cultivars grown in high tunnels in northern New England. HortTechnology 30:456-462, doi: 10.21273/HORTTECH 04577-20.

Silva, E. and D. Bruce. 2016. 2016 Northern Organic Vegetable Improvement Collaborative red pepper trial results. Univ. Wisconsin-Ext., Madison.

Simonne, E., J. Bannon, A. Caylor, J. Kemble, and J. Witt. 1996. Bell pepper performance depends on bacterial leaf spot susceptibility. Auburn Univ., Auburn, AL.

Simonne, E., B. Boozer, J. Little, J. Pitts, and M. Ruf. 1996. Colored pepper varieties respond differently to bacterial leaf spot infection. Auburn Univ., Auburn, AL.

Smigell, C., J. Strang, and J. Snyder. 2017. Bell pepper cultivar evaluation, 2017. Univ. Kentucky, Lexington.

Smigell, C., J. Strang, J. Snyder, and E. Pfeufer. 2018. Bell pepper cultivar evaluation, central Kentucky, 2018. Univ. Kentucky, Lexington.

Snyder, D. and A. Nair. 2019. Cultivar selection for colored pepper production. Iowa State Univ. Res. Demonstration Farms Prog. Rpt. 2018.

Stoffella, P.J., S.J. Locascio, T.K. Howe, S.M. Olson, K.D. Shuler, and C.S. Vavrina. 1995. Yield and fruit size stability differs among bell pepper cultivars. J. Amer. Soc. Hort. Sci. 120:325-328, doi: 10.21273/JASHS.120.2.325.

Strang, J., C. Smigell, L. Hanks, and J. Snyder. 2013. Bell pepper bacterial spot variety trial — 2013. Univ. Kentucky, Lexington.

Strang, J., J. Snyder, and C. Smigell. 2012. Bell pepper cultivar screening trial. Univ. Kentucky, Lexington.
Swamy, G.N. 2015. Evaluation of certain varieties and hybrids of capsicum for quality attributes under shade net. J. Hort. 2(1):1-4, doi: 10.4172/2376-0354.1000124.

Taber, H.G., N.P. Howell, and B.J. Havlovic. 2009. High tunnel pepper production. Iowa State Res. Farm Prog. Rpt. 463. 20 July 2020. <http://lib.dr.iastate.edu/farms_reports $/ 463>$.

Tuquero, J. and J. Bamba. 2016. Bell pepper (Capsicum annuum) a potential commercial crop for Guam. Food Plant Production. FPP-03. Univ. Guam, Mangilao.

Wagner, P., G. Matheke, D. Dinkel, and M. Griffith. 1989. Summary of vegetable variety trials, Fairbanks, Alaska, 1978-1985. Circ. 67. Univ. Alaska Fairbanks, Fairbanks.

Walters, S.A., J.R. Stieg, J.P. Bond, and M. Babadoost. 2007. Bell pepper cultivar evaluation under high Phytophthora capsici incidence. Southern Illinois Univ., Carbondale.

Wyatt, L.E., A.R. Dunn, M. Falise, S. Reiners, M. Jahn, C.D. Smart, and M. Mazourek. 2013. Red harvest yield and fruit characteristics of Phytophthora capsici-resistant bell pepper inbred lines in New York. HortTechnology 23:356-363, doi: 10.21273/HORTTECH.23.3.356.

Wyenandt, C.A., W.L. Kline, D.L. Ward, and N.L. Brill. 2017. Production system and cultivar effects on the development of skin separation or "silvering" in bell pepper fruit. HortTechnology 27:37-44, doi: 10.21273/ HORTTECH03144-16.

Zandstra, J.W. and R.C. Squire. 2007. Bacterial spot resistant pepper cultivar evaluation - 2007. Univ. Guelph, Ridgetown, ON, Canada. 
Supplemental Table 1. Tabulation of meta-analysis results for 85 broccoli varieties including mean relative yield and quality potential, lower and upper relative yield and quality potential (determined by the lower and upper bounds of the $95 \%$ confidence intervals around the mean), and the number of site-years and studies contributing to each estimate. Varieties are arranged in order of greatest (top) to lowest (bottom) mean relative yield. These data are also presented visually in the graphical summaries section of the Vegetable Variety Navigator. An "N/A" in an individual cell indicates insufficient replication for inclusion in the meta-analysis (less than three site-years).

\begin{tabular}{|c|c|c|c|c|c|c|c|c|c|c|}
\hline Variety & $\begin{array}{c}\text { Mean } \\
\text { relative } \\
\text { yield } \\
\text { potential } \\
(\%) \\
\end{array}$ & $\begin{array}{l}\text { Lower } \\
\text { relative } \\
\text { yield } \\
\text { potential } \\
(\%) \\
\end{array}$ & $\begin{array}{c}\text { Upper } \\
\text { relative } \\
\text { yield } \\
\text { potential } \\
(\%) \\
\end{array}$ & $\begin{array}{l}\text { Site- } \\
\text { years } \\
\text { (no.) }\end{array}$ & $\begin{array}{c}\text { Studies } \\
\text { (no.) }\end{array}$ & $\begin{array}{c}\text { Mean } \\
\text { relative } \\
\text { quality } \\
\text { potential } \\
(\%)\end{array}$ & $\begin{array}{c}\text { Lower } \\
\text { relative } \\
\text { quality } \\
\text { potential } \\
(\%)\end{array}$ & $\begin{array}{c}\text { Upper } \\
\text { relative } \\
\text { quality } \\
\text { potential } \\
(\%)\end{array}$ & $\begin{array}{c}\text { Site- } \\
\text { years } \\
\text { (no.) }\end{array}$ & $\begin{array}{c}\text { Studies } \\
\text { (no.) }\end{array}$ \\
\hline Green Gold & 27 & 5 & 51 & 15 & 6 & $\mathrm{~N} / \mathrm{A}$ & $\mathrm{N} / \mathrm{A}$ & $\mathrm{N} / \mathrm{A}$ & $\mathrm{N} / \mathrm{A}$ & $\mathrm{N} / \mathrm{A}$ \\
\hline Lucky & 19 & -3 & 46 & 6 & 3 & $\mathrm{~N} / \mathrm{A}$ & $\mathrm{N} / \mathrm{A}$ & $\mathrm{N} / \mathrm{A}$ & $\mathrm{N} / \mathrm{A}$ & $\mathrm{N} / \mathrm{A}$ \\
\hline Greenbelt & 17 & -17 & 51 & 6 & 3 & -19 & -34 & 3 & 17 & 10 \\
\hline Galaxy & 16 & 9 & 23 & 3 & 3 & 10 & -15 & 41 & 8 & 5 \\
\hline Batavia & 16 & -2 & 38 & 13 & 6 & -3 & -16 & 13 & 5 & 5 \\
\hline Chevalier & 15 & -7 & 42 & 3 & 3 & $\mathrm{~N} / \mathrm{A}$ & $\mathrm{N} / \mathrm{A}$ & $\mathrm{N} / \mathrm{A}$ & $\mathrm{N} / \mathrm{A}$ & $\mathrm{N} / \mathrm{A}$ \\
\hline Southern Comet & 15 & -5 & 38 & 4 & 4 & 21 & 5 & 36 & 5 & 5 \\
\hline Green Valient & 14 & -21 & 89 & 9 & 4 & $\mathrm{~N} / \mathrm{A}$ & $\mathrm{N} / \mathrm{A}$ & $\mathrm{N} / \mathrm{A}$ & $\mathrm{N} / \mathrm{A}$ & $\mathrm{N} / \mathrm{A}$ \\
\hline Legacy & 14 & -9 & 45 & 6 & 4 & -4 & -27 & 27 & 6 & 4 \\
\hline Imperial & 8 & -3 & 20 & 50 & 14 & 4 & -8 & 17 & 25 & 11 \\
\hline Green Magic & 8 & -5 & 23 & 41 & 20 & 8 & -1 & 18 & 25 & 15 \\
\hline Major & 8 & -21 & 44 & 7 & 6 & 6 & -1 & 14 & 5 & 4 \\
\hline Regal & 7 & -9 & 23 & 19 & 5 & -11 & -34 & 31 & 8 & 4 \\
\hline Green Goliath & 7 & -14 & 36 & 18 & 6 & 3 & -19 & 25 & 9 & 4 \\
\hline Neptune & 6 & -27 & 58 & 3 & 3 & 9 & -9 & 31 & 5 & 3 \\
\hline Majestic & 5 & -30 & 60 & 7 & 3 & $\mathrm{~N} / \mathrm{A}$ & $\mathrm{N} / \mathrm{A}$ & $\mathrm{N} / \mathrm{A}$ & $\mathrm{N} / \mathrm{A}$ & $\mathrm{N} / \mathrm{A}$ \\
\hline Luna & 4 & -12 & 23 & 13 & 6 & 18 & 11 & 26 & 13 & 6 \\
\hline Lieutenant & 3 & -6 & 13 & 13 & 5 & 24 & 7 & 44 & 11 & 4 \\
\hline Durapak 16 & 2 & -6 & 11 & 11 & 3 & $\mathrm{~N} / \mathrm{A}$ & $\mathrm{N} / \mathrm{A}$ & $\mathrm{N} / \mathrm{A}$ & $\mathrm{N} / \mathrm{A}$ & $\mathrm{N} / \mathrm{A}$ \\
\hline Emperor & 1 & -14 & 21 & 10 & 7 & -24 & -42 & 1 & 19 & 9 \\
\hline Laguna & -7 & -40 & 46 & 4 & 3 & 9 & -1 & 19 & 6 & 5 \\
\hline Green Comet & -8 & -30 & 23 & 5 & 3 & $\mathrm{~N} / \mathrm{A}$ & $\mathrm{N} / \mathrm{A}$ & $\mathrm{N} / \mathrm{A}$ & $\mathrm{N} / \mathrm{A}$ & $\mathrm{N} / \mathrm{A}$ \\
\hline Gypsy & -8 & -25 & 12 & 52 & 21 & -2 & -33 & 44 & 44 & 18 \\
\hline Captain & -9 & -30 & 18 & 17 & 11 & 0 & -10 & 10 & 10 & 8 \\
\hline Apollo & -10 & -39 & 33 & 4 & 3 & $\mathrm{~N} / \mathrm{A}$ & $\mathrm{N} / \mathrm{A}$ & $\mathrm{N} / \mathrm{A}$ & $\mathrm{N} / \mathrm{A}$ & $\mathrm{N} / \mathrm{A}$ \\
\hline Green Duke & -10 & -38 & 31 & 5 & 4 & 5 & -14 & 27 & 16 & 7 \\
\hline Arcadia & -10 & -26 & 2 & 46 & 17 & 7 & -4 & 19 & 30 & 14 \\
\hline Patron & -11 & -26 & 8 & 20 & 9 & 4 & -20 & 32 & 11 & 7 \\
\hline Castle Dome & -11 & -33 & 13 & 4 & 4 & $\mathrm{~N} / \mathrm{A}$ & $\mathrm{N} / \mathrm{A}$ & $\mathrm{N} / \mathrm{A}$ & $\mathrm{N} / \mathrm{A}$ & $\mathrm{N} / \mathrm{A}$ \\
\hline Claudia & -12 & -57 & 80 & 3 & 2 & $\mathrm{~N} / \mathrm{A}$ & $\mathrm{N} / \mathrm{A}$ & $\mathrm{N} / \mathrm{A}$ & $\mathrm{N} / \mathrm{A}$ & $\mathrm{N} / \mathrm{A}$ \\
\hline Burney & -12 & -22 & 0 & 11 & 3 & $\mathrm{~N} / \mathrm{A}$ & $\mathrm{N} / \mathrm{A}$ & $\mathrm{N} / \mathrm{A}$ & $\mathrm{N} / \mathrm{A}$ & $\mathrm{N} / \mathrm{A}$ \\
\hline Packman & -14 & -22 & -5 & 34 & 14 & 16 & 2 & 32 & 26 & 14 \\
\hline Excelsior & -14 & -37 & 10 & 16 & 4 & -6 & -26 & 20 & 9 & 6 \\
\hline Patriot & -15 & -26 & -2 & 11 & 4 & 20 & 7 & 34 & 3 & 3 \\
\hline Signal & -15 & -61 & 82 & 4 & 3 & $\mathrm{~N} / \mathrm{A}$ & $\mathrm{N} / \mathrm{A}$ & $\mathrm{N} / \mathrm{A}$ & $\mathrm{N} / \mathrm{A}$ & $\mathrm{N} / \mathrm{A}$ \\
\hline Destiny & -16 & -44 & 24 & 6 & 4 & $\mathrm{~N} / \mathrm{A}$ & $\mathrm{N} / \mathrm{A}$ & $\mathrm{N} / \mathrm{A}$ & $\mathrm{N} / \mathrm{A}$ & $\mathrm{N} / \mathrm{A}$ \\
\hline Diplomat & -16 & -26 & -5 & 25 & 9 & 11 & -4 & 27 & 15 & 8 \\
\hline
\end{tabular}


Supplemental Table 1. (Continued).

\begin{tabular}{|c|c|c|c|c|c|c|c|c|c|c|}
\hline Variety & $\begin{array}{c}\text { Mean } \\
\text { relative } \\
\text { yield } \\
\text { potential } \\
(\%) \\
\end{array}$ & $\begin{array}{c}\text { Lower } \\
\text { relative } \\
\text { yield } \\
\text { potential } \\
(\%) \\
\end{array}$ & $\begin{array}{c}\text { Upper } \\
\text { relative } \\
\text { yield } \\
\text { potential } \\
(\%) \\
\end{array}$ & $\begin{array}{l}\text { Site- } \\
\text { years } \\
\text { (no.) }\end{array}$ & $\begin{array}{c}\text { Studies } \\
\text { (no.) }\end{array}$ & $\begin{array}{c}\text { Mean } \\
\text { relative } \\
\text { quality } \\
\text { potential } \\
(\%)\end{array}$ & $\begin{array}{c}\text { Lower } \\
\text { relative } \\
\text { quality } \\
\text { potential } \\
(\%) \\
\end{array}$ & $\begin{array}{c}\text { Upper } \\
\text { relative } \\
\text { quality } \\
\text { potential } \\
(\%) \\
\end{array}$ & $\begin{array}{c}\text { Site- } \\
\text { years } \\
\text { (no.) }\end{array}$ & $\begin{array}{c}\text { Studies } \\
\text { (no.) }\end{array}$ \\
\hline Sultan & -17 & -27 & -2 & 15 & 6 & 7 & -2 & 17 & 11 & 8 \\
\hline Marathon & -17 & -37 & 9 & 38 & 17 & -12 & -22 & -1 & 18 & 10 \\
\hline Everest & -17 & -38 & 10 & 22 & 10 & 5 & -4 & 15 & 14 & 10 \\
\hline Heritage & -18 & -36 & 5 & 7 & 3 & 0 & -16 & 16 & 6 & 5 \\
\hline Belle Star & -20 & -35 & -1 & 42 & 16 & -15 & -33 & 6 & 25 & 10 \\
\hline Goliath & -20 & -24 & -16 & 5 & 3 & $\mathrm{~N} / \mathrm{A}$ & $\mathrm{N} / \mathrm{A}$ & $\mathrm{N} / \mathrm{A}$ & $\mathrm{N} / \mathrm{A}$ & $\mathrm{N} / \mathrm{A}$ \\
\hline Emerald Pride & -22 & -39 & 0 & 3 & 3 & 66 & 36 & 107 & 3 & 3 \\
\hline Avenger & -24 & -59 & 32 & 11 & 4 & -58 & -72 & -37 & 12 & 5 \\
\hline Emerald Jewel & -35 & -53 & -12 & 11 & 4 & $\mathrm{~N} / \mathrm{A}$ & $\mathrm{N} / \mathrm{A}$ & $\mathrm{N} / \mathrm{A}$ & $\mathrm{N} / \mathrm{A}$ & $\mathrm{N} / \mathrm{A}$ \\
\hline Monaco & -51 & -85 & 26 & 4 & 3 & $\mathrm{~N} / \mathrm{A}$ & $\mathrm{N} / \mathrm{A}$ & $\mathrm{N} / \mathrm{A}$ & $\mathrm{N} / \mathrm{A}$ & $\mathrm{N} / \mathrm{A}$ \\
\hline Expo & -56 & -88 & 43 & 11 & 3 & $\mathrm{~N} / \mathrm{A}$ & $\mathrm{N} / \mathrm{A}$ & $\mathrm{N} / \mathrm{A}$ & $\mathrm{N} / \mathrm{A}$ & $\mathrm{N} / \mathrm{A}$ \\
\hline Blue Wind & -56 & -83 & 2 & 12 & 5 & $\mathrm{~N} / \mathrm{A}$ & $\mathrm{N} / \mathrm{A}$ & $\mathrm{N} / \mathrm{A}$ & $\mathrm{N} / \mathrm{A}$ & $\mathrm{N} / \mathrm{A}$ \\
\hline Shogun & -61 & -91 & 68 & 3 & 3 & $\mathrm{~N} / \mathrm{A}$ & $\mathrm{N} / \mathrm{A}$ & $\mathrm{N} / \mathrm{A}$ & $\mathrm{N} / \mathrm{A}$ & $\mathrm{N} / \mathrm{A}$ \\
\hline Early Dividend & -89 & -96 & -65 & 3 & 3 & $\mathrm{~N} / \mathrm{A}$ & $\mathrm{N} / \mathrm{A}$ & $\mathrm{N} / \mathrm{A}$ & $\mathrm{N} / \mathrm{A}$ & $\mathrm{N} / \mathrm{A}$ \\
\hline Zeus & $\mathrm{N} / \mathrm{A}$ & $\mathrm{N} / \mathrm{A}$ & $\mathrm{N} / \mathrm{A}$ & $\mathrm{N} / \mathrm{A}$ & $\mathrm{N} / \mathrm{A}$ & 24 & -10 & 70 & 3 & 3 \\
\hline Alborada & $\mathrm{N} / \mathrm{A}$ & $\mathrm{N} / \mathrm{A}$ & $\mathrm{N} / \mathrm{A}$ & $\mathrm{N} / \mathrm{A}$ & $\mathrm{N} / \mathrm{A}$ & 14 & -10 & 56 & 4 & 4 \\
\hline Legend & $\mathrm{N} / \mathrm{A}$ & $\mathrm{N} / \mathrm{A}$ & $\mathrm{N} / \mathrm{A}$ & $\mathrm{N} / \mathrm{A}$ & $\mathrm{N} / \mathrm{A}$ & 6 & -10 & 26 & 5 & 4 \\
\hline Sprinter & $\mathrm{N} / \mathrm{A}$ & $\mathrm{N} / \mathrm{A}$ & $\mathrm{N} / \mathrm{A}$ & $\mathrm{N} / \mathrm{A}$ & $\mathrm{N} / \mathrm{A}$ & 5 & -20 & 38 & 4 & 4 \\
\hline Schooner & $\mathrm{N} / \mathrm{A}$ & $\mathrm{N} / \mathrm{A}$ & $\mathrm{N} / \mathrm{A}$ & $\mathrm{N} / \mathrm{A}$ & $\mathrm{N} / \mathrm{A}$ & -1 & -15 & 16 & 10 & 5 \\
\hline Citation & $\mathrm{N} / \mathrm{A}$ & $\mathrm{N} / \mathrm{A}$ & $\mathrm{N} / \mathrm{A}$ & $\mathrm{N} / \mathrm{A}$ & $\mathrm{N} / \mathrm{A}$ & -24 & -40 & -4 & 6 & 4 \\
\hline HMX 4138 & $\mathrm{~N} / \mathrm{A}$ & $\mathrm{N} / \mathrm{A}$ & $\mathrm{N} / \mathrm{A}$ & $\mathrm{N} / \mathrm{A}$ & $\mathrm{N} / \mathrm{A}$ & -24 & -47 & 3 & 5 & 3 \\
\hline Pirate & $\mathrm{N} / \mathrm{A}$ & $\mathrm{N} / \mathrm{A}$ & $\mathrm{N} / \mathrm{A}$ & $\mathrm{N} / \mathrm{A}$ & $\mathrm{N} / \mathrm{A}$ & -28 & -46 & -4 & 9 & 4 \\
\hline Commander & $\mathrm{N} / \mathrm{A}$ & $\mathrm{N} / \mathrm{A}$ & $\mathrm{N} / \mathrm{A}$ & $\mathrm{N} / \mathrm{A}$ & $\mathrm{N} / \mathrm{A}$ & -43 & -63 & -18 & 11 & 6 \\
\hline
\end{tabular}


Supplemental Table 2. Tabulation of meta-analysis results for 104 cucumber varieties including mean relative yield and quality potential, lower and upper relative yield and quality potential (determined by the lower and upper bounds of the $\mathbf{9 5 \%}$ confidence intervals around the mean), and the number of site-years and studies contributing to each estimate. Varieties are arranged in order of greatest (top) to lowest (bottom) mean relative yield. These data are also presented visually in the graphical summaries section of the Vegetable Variety Navigator. An "N/A" in an individual cell indicates insufficient replication for inclusion in the meta-analysis (less than three site-years).

\begin{tabular}{|c|c|c|c|c|c|c|c|c|c|c|}
\hline Variety & $\begin{array}{c}\text { Mean } \\
\text { relative } \\
\text { yield } \\
\text { potential } \\
(\%) \\
\end{array}$ & $\begin{array}{c}\text { Lower } \\
\text { relative } \\
\text { yield } \\
\text { potential } \\
(\%) \\
\end{array}$ & $\begin{array}{c}\text { Upper } \\
\text { relative } \\
\text { yield } \\
\text { potential } \\
(\%) \\
\end{array}$ & $\begin{array}{l}\text { Site- } \\
\text { years } \\
\text { (no.) }\end{array}$ & $\begin{array}{c}\text { Studies } \\
\text { (no.) }\end{array}$ & $\begin{array}{c}\text { Mean } \\
\text { relative } \\
\text { quality } \\
\text { potential } \\
(\%)\end{array}$ & $\begin{array}{c}\text { Lower } \\
\text { relative } \\
\text { quality } \\
\text { potential } \\
(\%)\end{array}$ & $\begin{array}{c}\text { Upper } \\
\text { relative } \\
\text { quality } \\
\text { potential } \\
(\%)\end{array}$ & $\begin{array}{l}\text { Site- } \\
\text { years } \\
\text { (no.) }\end{array}$ & $\begin{array}{c}\text { Studies } \\
\text { (no.) }\end{array}$ \\
\hline Alibi & 66 & 30 & 111 & 14 & 7 & 9 & -3 & 22 & 9 & 5 \\
\hline M 21 & 61 & -20 & 278 & 37 & 5 & 10 & -21 & 56 & 28 & 3 \\
\hline Liszt & 38 & 29 & 49 & 4 & 4 & 1 & -4 & 7 & 3 & 3 \\
\hline Atlantis & 36 & -3 & 92 & 9 & 7 & -7 & -16 & 1 & 4 & 4 \\
\hline Expedition & 36 & 17 & 56 & 8 & 6 & 21 & -6 & 56 & 5 & 5 \\
\hline Journey & 36 & 11 & 67 & 5 & 3 & 18 & 9 & 27 & 3 & 3 \\
\hline Lafayette & 35 & -7 & 99 & 6 & 4 & -1 & -24 & 29 & 3 & 3 \\
\hline Palomino & 29 & -2 & 71 & 5 & 3 & $\mathrm{~N} / \mathrm{A}$ & $\mathrm{N} / \mathrm{A}$ & $\mathrm{N} / \mathrm{A}$ & $\mathrm{N} / \mathrm{A}$ & $\mathrm{N} / \mathrm{A}$ \\
\hline Tasty Green & 29 & -23 & 116 & 16 & 10 & 9 & -5 & 24 & 9 & 7 \\
\hline Socrates & 26 & 14 & 38 & 7 & 6 & 0 & -5 & 6 & 4 & 3 \\
\hline Tasty Jade & 22 & 7 & 38 & 8 & 5 & -5 & -15 & 3 & 6 & 5 \\
\hline Earlipik 14 & 21 & 4 & 40 & 27 & 3 & 14 & -1 & 32 & 27 & 3 \\
\hline Pik Rite & 20 & 6 & 35 & 5 & 5 & -7 & -12 & -2 & 3 & 3 \\
\hline Sprint 440 & 20 & 9 & 31 & 9 & 6 & 12 & 0 & 25 & 8 & 5 \\
\hline Score & 19 & 1 & 39 & 8 & 6 & 0 & -5 & 5 & 5 & 4 \\
\hline Regal & 18 & -1 & 38 & 33 & 4 & 2 & -33 & 60 & 28 & 5 \\
\hline Rubinstein & 18 & -5 & 47 & 3 & 3 & $\mathrm{~N} / \mathrm{A}$ & $\mathrm{N} / \mathrm{A}$ & $\mathrm{N} / \mathrm{A}$ & $\mathrm{N} / \mathrm{A}$ & $\mathrm{N} / \mathrm{A}$ \\
\hline Beit Alpha & 16 & -22 & 73 & 10 & 5 & $\mathrm{~N} / \mathrm{A}$ & $\mathrm{N} / \mathrm{A}$ & $\mathrm{N} / \mathrm{A}$ & $\mathrm{N} / \mathrm{A}$ & $\mathrm{N} / \mathrm{A}$ \\
\hline Fancipak & 16 & -12 & 49 & 11 & 8 & 3 & -5 & 12 & 4 & 4 \\
\hline Talladaga & 14 & -18 & 59 & 5 & 3 & $\mathrm{~N} / \mathrm{A}$ & $\mathrm{N} / \mathrm{A}$ & $\mathrm{N} / \mathrm{A}$ & $\mathrm{N} / \mathrm{A}$ & $\mathrm{N} / \mathrm{A}$ \\
\hline Vlaspik & 13 & -12 & 46 & 10 & 8 & 5 & -9 & 21 & 7 & 6 \\
\hline Gershwin & 11 & -7 & 32 & 7 & 7 & 0 & -5 & 4 & 5 & 5 \\
\hline Super Marketer & 11 & -25 & 50 & 7 & 3 & $\mathrm{~N} / \mathrm{A}$ & $\mathrm{N} / \mathrm{A}$ & $\mathrm{N} / \mathrm{A}$ & $\mathrm{N} / \mathrm{A}$ & $\mathrm{N} / \mathrm{A}$ \\
\hline USACX 10428 & 11 & -7 & 31 & 5 & 4 & 12 & -1 & 26 & 5 & 4 \\
\hline Sweet Success & 10 & -25 & 52 & 6 & 5 & $\mathrm{~N} / \mathrm{A}$ & $\mathrm{N} / \mathrm{A}$ & $\mathrm{N} / \mathrm{A}$ & $\mathrm{N} / \mathrm{A}$ & $\mathrm{N} / \mathrm{A}$ \\
\hline Carolina & 9 & -9 & 30 & 44 & 15 & 7 & -1 & 16 & 32 & 7 \\
\hline Cherokee & 9 & -27 & 48 & 6 & 3 & $\mathrm{~N} / \mathrm{A}$ & $\mathrm{N} / \mathrm{A}$ & $\mathrm{N} / \mathrm{A}$ & $\mathrm{N} / \mathrm{A}$ & $\mathrm{N} / \mathrm{A}$ \\
\hline Duke & 9 & -2 & 20 & 5 & 5 & 2 & -13 & 19 & 3 & 3 \\
\hline Flurry & 8 & -18 & 45 & 10 & 6 & 3 & -3 & 9 & 5 & 4 \\
\hline Tamor & 7 & -3 & 18 & 8 & 5 & 2 & -5 & 9 & 6 & 3 \\
\hline Thunder & 7 & -6 & 22 & 9 & 6 & -6 & -17 & 6 & 4 & 3 \\
\hline Manny & 6 & -10 & 27 & 5 & 3 & -8 & -12 & -4 & 4 & 3 \\
\hline Lisboa & 5 & -4 & 17 & 8 & 6 & -5 & -16 & 9 & 7 & 6 \\
\hline General Lee & 4 & -7 & 16 & 9 & 7 & 13 & -10 & 42 & 5 & 4 \\
\hline Greensleeves & 3 & -20 & 31 & 6 & 4 & 28 & -5 & 68 & 3 & 3 \\
\hline Rockingham & 3 & -7 & 14 & 4 & 4 & $\mathrm{~N} / \mathrm{A}$ & $\mathrm{N} / \mathrm{A}$ & $\mathrm{N} / \mathrm{A}$ & $\mathrm{N} / \mathrm{A}$ & $\mathrm{N} / \mathrm{A}$ \\
\hline Sassy & 3 & -22 & 37 & 9 & 5 & 5 & -9 & 22 & 6 & 5 \\
\hline Dominator & 2 & -10 & 17 & 4 & 4 & $\mathrm{~N} / \mathrm{A}$ & $\mathrm{N} / \mathrm{A}$ & $\mathrm{N} / \mathrm{A}$ & $\mathrm{N} / \mathrm{A}$ & $\mathrm{N} / \mathrm{A}$ \\
\hline Feisty & 2 & -30 & 49 & 6 & 6 & -18 & -44 & 19 & 4 & 3 \\
\hline Pioneer & 2 & -18 & 26 & 32 & 6 & 6 & -5 & 19 & 29 & 3 \\
\hline Superior & 2 & -7 & 12 & 4 & 4 & 2 & -5 & 10 & 6 & 5 \\
\hline Genuine & 1 & -12 & 17 & 5 & 5 & $\mathrm{~N} / \mathrm{A}$ & $\mathrm{N} / \mathrm{A}$ & $\mathrm{N} / \mathrm{A}$ & $\mathrm{N} / \mathrm{A}$ & $\mathrm{N} / \mathrm{A}$ \\
\hline Speedway & 1 & -13 & 17 & 8 & 7 & 21 & 3 & 40 & 4 & 4 \\
\hline Cobra & -1 & -6 & 4 & 11 & 11 & -2 & -6 & 2 & 8 & 7 \\
\hline Dasher II & -1 & -13 & 14 & 27 & 18 & 19 & 0 & 42 & 13 & 13 \\
\hline SV 3462 CS & -1 & -18 & 20 & 5 & 5 & -6 & -20 & 10 & 4 & 3 \\
\hline SV 4719 CS & -1 & -13 & 13 & 11 & 8 & -2 & -8 & 5 & 6 & 5 \\
\hline Bowie & -2 & -16 & 13 & 6 & 6 & -3 & -10 & 5 & 4 & 4 \\
\hline Artist & -3 & -16 & 11 & 6 & 5 & 2 & -5 & 8 & 4 & 4 \\
\hline SX 2387 CW & -4 & -13 & 9 & 3 & 3 & $\mathrm{~N} / \mathrm{A}$ & $\mathrm{N} / \mathrm{A}$ & $\mathrm{N} / \mathrm{A}$ & $\mathrm{N} / \mathrm{A}$ & $\mathrm{N} / \mathrm{A}$ \\
\hline
\end{tabular}


Supplemental Table 2. (Continued).

\begin{tabular}{|c|c|c|c|c|c|c|c|c|c|c|}
\hline Variety & $\begin{array}{c}\text { Mean } \\
\text { relative } \\
\text { yield } \\
\text { potential } \\
(\%) \\
\end{array}$ & $\begin{array}{c}\text { Lower } \\
\text { relative } \\
\text { yield } \\
\text { potential } \\
(\%) \\
\end{array}$ & $\begin{array}{c}\text { Upper } \\
\text { relative } \\
\text { yield } \\
\text { potential } \\
(\%) \\
\end{array}$ & $\begin{array}{l}\text { Site- } \\
\text { years } \\
\text { (no.) }\end{array}$ & $\begin{array}{c}\text { Studies } \\
\text { (no.) }\end{array}$ & $\begin{array}{c}\text { Mean } \\
\text { relative } \\
\text { quality } \\
\text { potential } \\
(\%) \\
\end{array}$ & $\begin{array}{c}\text { Lower } \\
\text { relative } \\
\text { quality } \\
\text { potential } \\
(\%) \\
\end{array}$ & $\begin{array}{c}\text { Upper } \\
\text { relative } \\
\text { quality } \\
\text { potential } \\
(\%) \\
\end{array}$ & $\begin{array}{l}\text { Site- } \\
\text { years } \\
\text { (no.) }\end{array}$ & $\begin{array}{c}\text { Studies } \\
\text { (no.) }\end{array}$ \\
\hline Poinsett & -7 & -21 & 9 & 12 & 6 & $\mathrm{~N} / \mathrm{A}$ & $\mathrm{N} / \mathrm{A}$ & $\mathrm{N} / \mathrm{A}$ & $\mathrm{N} / \mathrm{A}$ & $\mathrm{N} / \mathrm{A}$ \\
\hline Triplemech & -9 & -31 & 22 & 9 & 6 & -3 & -8 & 1 & 7 & 4 \\
\hline Darlington & -11 & -17 & -4 & 5 & 6 & 2 & -10 & 18 & 5 & 5 \\
\hline Intimidator & -12 & -30 & 10 & 9 & 7 & 28 & -5 & 69 & 3 & 3 \\
\hline Impact & -13 & -24 & -2 & 8 & 7 & 8 & -3 & 21 & 6 & 5 \\
\hline Salad Bush & -13 & -36 & 17 & 3 & 3 & $\mathrm{~N} / \mathrm{A}$ & $\mathrm{N} / \mathrm{A}$ & $\mathrm{N} / \mathrm{A}$ & $\mathrm{N} / \mathrm{A}$ & $\mathrm{N} / \mathrm{A}$ \\
\hline Calypso & -14 & -41 & 26 & 53 & 10 & 18 & 9 & 27 & 40 & 11 \\
\hline Indy & -14 & -49 & 47 & 9 & 9 & 19 & -1 & 41 & 4 & 4 \\
\hline Yamato Sanjaku & -21 & -39 & 3 & 5 & 3 & -55 & -81 & 1 & 3 & 3 \\
\hline Marketer & -24 & -34 & -13 & 7 & 4 & $\mathrm{~N} / \mathrm{A}$ & $\mathrm{N} / \mathrm{A}$ & $\mathrm{N} / \mathrm{A}$ & $\mathrm{N} / \mathrm{A}$ & $\mathrm{N} / \mathrm{A}$ \\
\hline Vlasset & -25 & -58 & 32 & 6 & 4 & $\mathrm{~N} / \mathrm{A}$ & $\mathrm{N} / \mathrm{A}$ & $\mathrm{N} / \mathrm{A}$ & $\mathrm{N} / \mathrm{A}$ & $\mathrm{N} / \mathrm{A}$ \\
\hline Bounty & -26 & -47 & 3 & 9 & 3 & 0 & -4 & 5 & 8 & 3 \\
\hline HMX 0469 & -26 & -34 & -17 & 3 & 3 & $\mathrm{~N} / \mathrm{A}$ & $\mathrm{N} / \mathrm{A}$ & $\mathrm{N} / \mathrm{A}$ & $\mathrm{N} / \mathrm{A}$ & $\mathrm{N} / \mathrm{A}$ \\
\hline Yildo & -26 & -36 & -14 & 4 & 2 & 4 & -7 & 14 & 3 & 3 \\
\hline Ashley & -32 & -61 & 24 & 25 & 12 & -32 & -81 & 99 & 3 & 3 \\
\hline Martini & -33 & -78 & 102 & 10 & 4 & -43 & -87 & 155 & 6 & 4 \\
\hline Clinton & -35 & -43 & -25 & 27 & 3 & -27 & -36 & -16 & 28 & 4 \\
\hline Panther & -36 & -61 & 4 & 5 & 3 & $\mathrm{~N} / \mathrm{A}$ & $\mathrm{N} / \mathrm{A}$ & $\mathrm{N} / \mathrm{A}$ & $\mathrm{N} / \mathrm{A}$ & $\mathrm{N} / \mathrm{A}$ \\
\hline Tyria & -36 & -53 & -10 & 5 & 4 & 5 & -15 & 32 & 4 & 3 \\
\hline Poinsett 76 & -45 & -71 & 9 & 17 & 10 & 4 & -8 & 18 & 9 & 6 \\
\hline Eureka & -51 & -84 & 44 & 9 & 9 & 18 & 9 & 27 & 4 & 4 \\
\hline Sultan & -53 & -58 & -48 & 3 & 3 & $\mathrm{~N} / \mathrm{A}$ & $\mathrm{N} / \mathrm{A}$ & $\mathrm{N} / \mathrm{A}$ & $\mathrm{N} / \mathrm{A}$ & $\mathrm{N} / \mathrm{A}$ \\
\hline Japanese Climbing & -59 & -82 & -5 & 5 & 4 & $\mathrm{~N} / \mathrm{A}$ & $\mathrm{N} / \mathrm{A}$ & $\mathrm{N} / \mathrm{A}$ & $\mathrm{N} / \mathrm{A}$ & $\mathrm{N} / \mathrm{A}$ \\
\hline Cross Country & -63 & -90 & 30 & 9 & 7 & 8 & -3 & 22 & 5 & 5 \\
\hline Marketmore 76 & -70 & -85 & -41 & 36 & 21 & 2 & -5 & 8 & 16 & 10 \\
\hline Fanfare & -76 & -91 & -39 & 7 & 5 & $\mathrm{~N} / \mathrm{A}$ & $\mathrm{N} / \mathrm{A}$ & $\mathrm{N} / \mathrm{A}$ & $\mathrm{N} / \mathrm{A}$ & $\mathrm{N} / \mathrm{A}$ \\
\hline SMR 58 & -76 & -94 & -8 & 7 & 5 & -16 & -29 & 0 & 3 & 3 \\
\hline Wautoma & -76 & -92 & -28 & 27 & 2 & $\mathrm{~N} / \mathrm{A}$ & $\mathrm{N} / \mathrm{A}$ & $\mathrm{N} / \mathrm{A}$ & $\mathrm{N} / \mathrm{A}$ & $\mathrm{N} / \mathrm{A}$ \\
\hline Sweeter Yet & -80 & -95 & -23 & 3 & 3 & $\mathrm{~N} / \mathrm{A}$ & $\mathrm{N} / \mathrm{A}$ & $\mathrm{N} / \mathrm{A}$ & $\mathrm{N} / \mathrm{A}$ & $\mathrm{N} / \mathrm{A}$ \\
\hline WI 2238 & -82 & -98 & 38 & 5 & 4 & $\mathrm{~N} / \mathrm{A}$ & $\mathrm{N} / \mathrm{A}$ & $\mathrm{N} / \mathrm{A}$ & $\mathrm{N} / \mathrm{A}$ & $\mathrm{N} / \mathrm{A}$ \\
\hline WI 2757 & -84 & -93 & -63 & 31 & 4 & $\mathrm{~N} / \mathrm{A}$ & $\mathrm{N} / \mathrm{A}$ & $\mathrm{N} / \mathrm{A}$ & $\mathrm{N} / \mathrm{A}$ & $\mathrm{N} / \mathrm{A}$ \\
\hline SMR 18 & -88 & -93 & -79 & 35 & 4 & $\mathrm{~N} / \mathrm{A}$ & $\mathrm{N} / \mathrm{A}$ & $\mathrm{N} / \mathrm{A}$ & $\mathrm{N} / \mathrm{A}$ & $\mathrm{N} / \mathrm{A}$ \\
\hline WI SMR 18 & -89 & -94 & -79 & 33 & 4 & $\mathrm{~N} / \mathrm{A}$ & $\mathrm{N} / \mathrm{A}$ & $\mathrm{N} / \mathrm{A}$ & $\mathrm{N} / \mathrm{A}$ & $\mathrm{N} / \mathrm{A}$ \\
\hline H-19 (Little Leaf) & -92 & -99 & -35 & 10 & 7 & $\mathrm{~N} / \mathrm{A}$ & $\mathrm{N} / \mathrm{A}$ & $\mathrm{N} / \mathrm{A}$ & $\mathrm{N} / \mathrm{A}$ & $\mathrm{N} / \mathrm{A}$ \\
\hline Straight Eight & -97 & -99 & -79 & 13 & 7 & 0 & -9 & 11 & 4 & 3 \\
\hline Ansor & $\mathrm{N} / \mathrm{A}$ & $\mathrm{N} / \mathrm{A}$ & $\mathrm{N} / \mathrm{A}$ & $\mathrm{N} / \mathrm{A}$ & $\mathrm{N} / \mathrm{A}$ & 0 & -2 & 3 & 3 & 3 \\
\hline Discover $M$ & $\mathrm{~N} / \mathrm{A}$ & $\mathrm{N} / \mathrm{A}$ & $\mathrm{N} / \mathrm{A}$ & $\mathrm{N} / \mathrm{A}$ & $\mathrm{N} / \mathrm{A}$ & 16 & -7 & 43 & 4 & 3 \\
\hline Flurry M & $\mathrm{N} / \mathrm{A}$ & $\mathrm{N} / \mathrm{A}$ & $\mathrm{N} / \mathrm{A}$ & $\mathrm{N} / \mathrm{A}$ & $\mathrm{N} / \mathrm{A}$ & 1 & -5 & 6 & 3 & 3 \\
\hline Premier & $\mathrm{N} / \mathrm{A}$ & $\mathrm{N} / \mathrm{A}$ & $\mathrm{N} / \mathrm{A}$ & $\mathrm{N} / \mathrm{A}$ & $\mathrm{N} / \mathrm{A}$ & -4 & -11 & 6 & 4 & 4 \\
\hline USACX 10429 & $\mathrm{~N} / \mathrm{A}$ & $\mathrm{N} / \mathrm{A}$ & $\mathrm{N} / \mathrm{A}$ & $\mathrm{N} / \mathrm{A}$ & $\mathrm{N} / \mathrm{A}$ & 9 & -11 & 34 & 5 & 4 \\
\hline
\end{tabular}


Supplemental Table 3. Tabulation of meta-analysis results for 144 pepper varieties including mean relative yield and quality potential, lower and upper relative yield and quality potential (determined by the lower and upper bounds of the $95 \%$ confidence intervals around the mean), and the number of site-years and studies contributing to each estimate. Varieties are arranged in order of greatest (top) to lowest (bottom) mean relative yield. These data are also presented visually in the graphical summaries section of the Vegetable Variety Navigator. An "N/A" in an individual cell indicates insufficient replication for inclusion in the meta-analysis (less than three site-years).

\begin{tabular}{|c|c|c|c|c|c|c|c|c|c|c|}
\hline Variety & $\begin{array}{c}\text { Mean } \\
\text { relative } \\
\text { yield } \\
\text { potential } \\
(\%) \\
\end{array}$ & $\begin{array}{c}\text { Lower } \\
\text { relative } \\
\text { yield } \\
\text { potential } \\
(\%) \\
\end{array}$ & $\begin{array}{c}\text { Upper } \\
\text { relative } \\
\text { yield } \\
\text { potential } \\
(\%) \\
\end{array}$ & $\begin{array}{l}\text { Site- } \\
\text { years } \\
\text { (no.) }\end{array}$ & $\begin{array}{c}\text { Studies } \\
\text { (no.) }\end{array}$ & $\begin{array}{c}\text { Mean } \\
\text { relative } \\
\text { quality } \\
\text { potential } \\
(\%) \\
\end{array}$ & $\begin{array}{c}\text { Lower } \\
\text { relative } \\
\text { quality } \\
\text { potential } \\
(\%) \\
\end{array}$ & $\begin{array}{c}\text { Upper } \\
\text { relative } \\
\text { quality } \\
\text { potential } \\
(\%) \\
\end{array}$ & $\begin{array}{c}\text { Site- } \\
\text { years } \\
\text { (no.) }\end{array}$ & $\begin{array}{c}\text { Studies } \\
\text { (no.) }\end{array}$ \\
\hline Ace & 63 & 27 & 109 & 14 & 11 & -66 & -90 & 13 & 5 & 3 \\
\hline Tequila & 58 & -40 & 346 & 14 & 7 & $\mathrm{~N} / \mathrm{A}$ & $\mathrm{N} / \mathrm{A}$ & $\mathrm{N} / \mathrm{A}$ & $\mathrm{N} / \mathrm{A}$ & $\mathrm{N} / \mathrm{A}$ \\
\hline New Ace & 47 & 6 & 107 & 10 & 7 & 19 & -2 & 43 & 7 & 7 \\
\hline Flamingo & 30 & 18 & 43 & 3 & 3 & -5 & -17 & 8 & 4 & 3 \\
\hline Sweet Chocolate & 30 & 12 & 51 & 5 & 3 & 5 & -3 & 15 & 21 & 6 \\
\hline Red Dawn & 30 & 4 & 61 & 3 & 3 & 10 & 2 & 18 & 16 & 14 \\
\hline Colossal & 29 & 9 & 55 & 5 & 4 & -1 & -7 & 6 & 5 & 5 \\
\hline Argo & 21 & 13 & 30 & 3 & 3 & -12 & -27 & 10 & 5 & 5 \\
\hline Lady Bell & 18 & 8 & 30 & 13 & 12 & -8 & -28 & 16 & 4 & 3 \\
\hline Honeybelle & 18 & 2 & 38 & 3 & 3 & 8 & -2 & 20 & 12 & 10 \\
\hline Vivaldi & 17 & -18 & 65 & 6 & 4 & -52 & -70 & -25 & 7 & 6 \\
\hline Turnpike & 17 & 0 & 36 & 7 & 6 & -20 & -47 & 20 & 8 & 7 \\
\hline Green Boy & 16 & 11 & 21 & 4 & 4 & -5 & -9 & -1 & 3 & 3 \\
\hline Antebellum & 16 & 1 & 34 & 4 & 3 & -11 & -35 & 21 & 3 & 3 \\
\hline Domino & 14 & 1 & 29 & 5 & 5 & -2 & -18 & 21 & 4 & 4 \\
\hline North Star & 14 & -3 & 35 & 10 & 8 & 6 & 0 & 11 & 3 & 3 \\
\hline Declaration & 14 & 7 & 22 & 17 & 16 & -40 & -57 & -15 & 9 & 4 \\
\hline Boynton Bell & 13 & 0 & 29 & 22 & 13 & $\mathrm{~N} / \mathrm{A}$ & $\mathrm{N} / \mathrm{A}$ & $\mathrm{N} / \mathrm{A}$ & $\mathrm{N} / \mathrm{A}$ & $\mathrm{N} / \mathrm{A}$ \\
\hline Mayata & 13 & -11 & 40 & 3 & 3 & -7 & -13 & -2 & 3 & 3 \\
\hline Bell King & 13 & -7 & 37 & 5 & 5 & 7 & -8 & 25 & 9 & 6 \\
\hline La Belle & 13 & -5 & 33 & 3 & 2 & $\mathrm{~N} / \mathrm{A}$ & $\mathrm{N} / \mathrm{A}$ & $\mathrm{N} / \mathrm{A}$ & $\mathrm{N} / \mathrm{A}$ & $\mathrm{N} / \mathrm{A}$ \\
\hline Enterprise & 12 & -2 & 28 & 8 & 6 & 10 & 0 & 21 & 32 & 21 \\
\hline Sentry & 11 & 3 & 21 & 3 & 3 & $\mathrm{~N} / \mathrm{A}$ & $\mathrm{N} / \mathrm{A}$ & $\mathrm{N} / \mathrm{A}$ & $\mathrm{N} / \mathrm{A}$ & $\mathrm{N} / \mathrm{A}$ \\
\hline Merlin & 10 & -1 & 22 & 6 & 6 & $\mathrm{~N} / \mathrm{A}$ & $\mathrm{N} / \mathrm{A}$ & $\mathrm{N} / \mathrm{A}$ & $\mathrm{N} / \mathrm{A}$ & $\mathrm{N} / \mathrm{A}$ \\
\hline Hybelle & 10 & -4 & 24 & 6 & 6 & -10 & -25 & 8 & 5 & 5 \\
\hline Lafayette & 9 & -3 & 23 & 14 & 13 & 1 & -9 & 11 & 19 & 13 \\
\hline Karisma & 9 & 4 & 15 & 28 & 24 & -4 & -5 & -3 & 4 & 3 \\
\hline Excursion II & 9 & 4 & 14 & 15 & 12 & -10 & -23 & 2 & 3 & 3 \\
\hline Chesapeake & 8 & -4 & 25 & 3 & 3 & -13 & -28 & 11 & 4 & 4 \\
\hline Early Red Sweet & 8 & -6 & 26 & 6 & 3 & 18 & 0 & 44 & 4 & 4 \\
\hline Galileo & 8 & -3 & 19 & 4 & 4 & -9 & -24 & 10 & 4 & 3 \\
\hline Bell Boy & 8 & -6 & 24 & 7 & 7 & -6 & -18 & 13 & 4 & 4 \\
\hline Gedeon & 7 & -2 & 18 & 3 & 3 & -18 & -32 & 3 & 3 & 3 \\
\hline Shamrock & 7 & -14 & 34 & 4 & 4 & 12 & -3 & 26 & 3 & 3 \\
\hline Boca & 7 & 2 & 11 & 6 & 5 & -6 & -21 & 14 & 3 & 3 \\
\hline Staddon Select & 6 & -3 & 17 & 5 & 5 & -17 & -28 & -5 & 4 & 4 \\
\hline PS 0994-1819 & 6 & 1 & 11 & 13 & 11 & -14 & -28 & 1 & 6 & 5 \\
\hline Blitz & 5 & -4 & 15 & 9 & 8 & 1 & -7 & 9 & 26 & 22 \\
\hline Vanguard & 5 & 0 & 11 & 26 & 24 & $\mathrm{~N} / \mathrm{A}$ & $\mathrm{N} / \mathrm{A}$ & $\mathrm{N} / \mathrm{A}$ & $\mathrm{N} / \mathrm{A}$ & $\mathrm{N} / \mathrm{A}$ \\
\hline Gridiron & 5 & -5 & 16 & 7 & 5 & 19 & 11 & 27 & 12 & 9 \\
\hline Currier & 5 & -3 & 13 & 11 & 11 & $\mathrm{~N} / \mathrm{A}$ & $\mathrm{N} / \mathrm{A}$ & $\mathrm{N} / \mathrm{A}$ & $\mathrm{N} / \mathrm{A}$ & $\mathrm{N} / \mathrm{A}$ \\
\hline Telestar & 5 & -3 & 13 & 7 & 6 & $\mathrm{~N} / \mathrm{A}$ & $\mathrm{N} / \mathrm{A}$ & $\mathrm{N} / \mathrm{A}$ & $\mathrm{N} / \mathrm{A}$ & $\mathrm{N} / \mathrm{A}$ \\
\hline Lantern & 5 & -4 & 13 & 8 & 3 & -4 & -18 & 12 & 6 & 5 \\
\hline Sandpiper & 4 & -8 & 17 & 3 & 3 & -24 & -38 & -10 & 7 & 6 \\
\hline Big Belle & 4 & -2 & 11 & 4 & 4 & -6 & -22 & 14 & 9 & 9 \\
\hline SV 3255 PB & 4 & -3 & 10 & 5 & 5 & -8 & -15 & 2 & 3 & 3 \\
\hline Belle Star & 3 & -5 & 14 & 3 & 3 & -1 & -19 & 23 & 6 & 5 \\
\hline MA 79259 & 3 & -5 & 12 & 3 & 3 & $\mathrm{~N} / \mathrm{A}$ & $\mathrm{N} / \mathrm{A}$ & $\mathrm{N} / \mathrm{A}$ & $\mathrm{N} / \mathrm{A}$ & $\mathrm{N} / \mathrm{A}$ \\
\hline 8302 & 2 & -26 & 42 & 5 & 3 & 19 & -7 & 52 & 10 & 8 \\
\hline
\end{tabular}


Supplemental Table 3. (Continued).

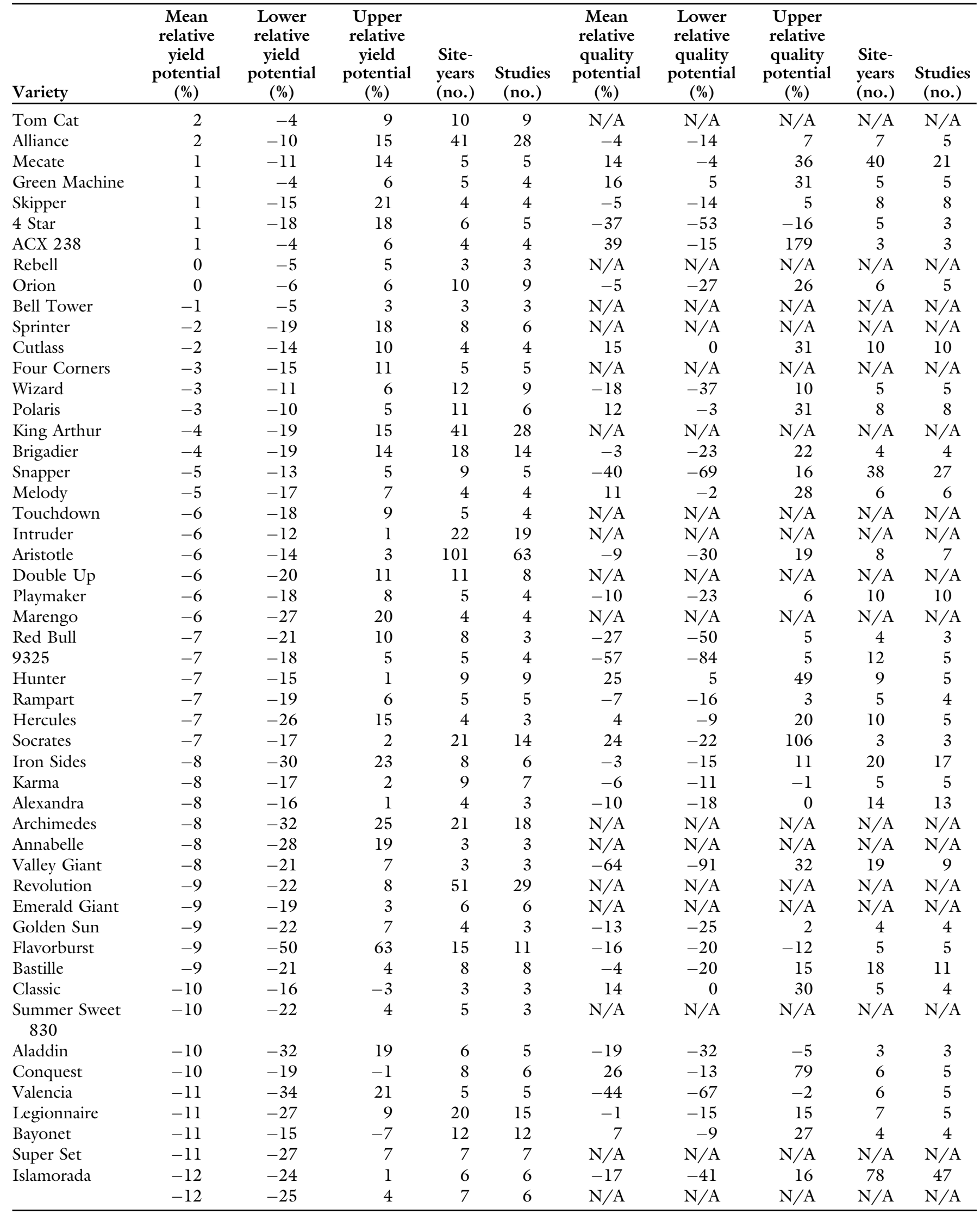

(Continued on next page) 
Supplemental Table 3. (Continued).

\begin{tabular}{|c|c|c|c|c|c|c|c|c|c|c|}
\hline Variety & $\begin{array}{c}\text { Mean } \\
\text { relative } \\
\text { yield } \\
\text { potential } \\
(\%)\end{array}$ & $\begin{array}{l}\text { Lower } \\
\text { relative } \\
\text { yield } \\
\text { potential } \\
(\%)\end{array}$ & $\begin{array}{c}\text { Upper } \\
\text { relative } \\
\text { yield } \\
\text { potential } \\
(\%)\end{array}$ & $\begin{array}{l}\text { Site- } \\
\text { years } \\
\text { (no.) } \\
\end{array}$ & $\begin{array}{c}\text { Studies } \\
\text { (no.) }\end{array}$ & $\begin{array}{c}\text { Mean } \\
\text { relative } \\
\text { quality } \\
\text { potential } \\
(\%)\end{array}$ & $\begin{array}{c}\text { Lower } \\
\text { relative } \\
\text { quality } \\
\text { potential } \\
(\%)\end{array}$ & $\begin{array}{c}\text { Upper } \\
\text { relative } \\
\text { quality } \\
\text { potential } \\
(\%)\end{array}$ & $\begin{array}{l}\text { Site- } \\
\text { years } \\
\text { (no.) }\end{array}$ & $\begin{array}{c}\text { Studies } \\
\text { (no.) }\end{array}$ \\
\hline $\begin{array}{l}\text { Keystone } \\
\text { Resistant } \\
\text { Giant }\end{array}$ & & & & & & & & & & \\
\hline Abay & -14 & -25 & 0 & 4 & 4 & 11 & -13 & 43 & 3 & 3 \\
\hline Better Belle & -14 & -33 & 10 & 4 & 3 & -8 & -19 & 5 & 5 & 5 \\
\hline Patriot & -15 & -28 & 0 & 20 & 18 & -22 & -37 & -3 & 4 & 4 \\
\hline Heritage & -15 & -36 & 13 & 12 & 12 & -11 & -24 & 4 & 30 & 19 \\
\hline Paladin & -16 & -29 & -1 & 69 & 27 & -11 & -21 & 1 & 9 & 6 \\
\hline Mahi & -21 & -35 & -6 & 4 & 4 & 9 & 4 & 14 & 15 & 15 \\
\hline Crusader & -21 & -40 & 2 & 15 & 13 & 5 & -2 & 13 & 21 & 20 \\
\hline Olympus & -22 & -37 & -4 & 13 & 12 & $\mathrm{~N} / \mathrm{A}$ & $\mathrm{N} / \mathrm{A}$ & $\mathrm{N} / \mathrm{A}$ & $\mathrm{N} / \mathrm{A}$ & $\mathrm{N} / \mathrm{A}$ \\
\hline Red Knight & -22 & -37 & -5 & 42 & 32 & 7 & 1 & 15 & 11 & 11 \\
\hline $\begin{array}{l}\text { King of the } \\
\text { North }\end{array}$ & -23 & -43 & 6 & 7 & 4 & -1 & -5 & 2 & 10 & 9 \\
\hline Dashen & -24 & -40 & -2 & 8 & 7 & -4 & -15 & 9 & 4 & 4 \\
\hline Bell Captain & -25 & -38 & -7 & 4 & 4 & $\mathrm{~N} / \mathrm{A}$ & $\mathrm{N} / \mathrm{A}$ & $\mathrm{N} / \mathrm{A}$ & $\mathrm{N} / \mathrm{A}$ & $\mathrm{N} / \mathrm{A}$ \\
\hline Procraft & -26 & -45 & -1 & 8 & 5 & 16 & -8 & 46 & 5 & 5 \\
\hline Allegiance & -26 & -46 & 0 & 4 & 3 & 0 & -12 & 12 & 4 & 4 \\
\hline Blushing Beauty & -29 & -55 & 11 & 7 & 7 & 1 & -16 & 23 & 13 & 10 \\
\hline Early Sunsation & -44 & -70 & 1 & 19 & 9 & -10 & -21 & 4 & 4 & 4 \\
\hline Admiral & -52 & -78 & 4 & 5 & 3 & $\mathrm{~N} / \mathrm{A}$ & $\mathrm{N} / \mathrm{A}$ & $\mathrm{N} / \mathrm{A}$ & $\mathrm{N} / \mathrm{A}$ & $\mathrm{N} / \mathrm{A}$ \\
\hline Gourmet & -52 & -75 & -8 & 6 & 5 & $\mathrm{~N} / \mathrm{A}$ & $\mathrm{N} / \mathrm{A}$ & $\mathrm{N} / \mathrm{A}$ & $\mathrm{N} / \mathrm{A}$ & $\mathrm{N} / \mathrm{A}$ \\
\hline Delirio & -69 & -93 & 34 & 4 & 4 & $\mathrm{~N} / \mathrm{A}$ & $\mathrm{N} / \mathrm{A}$ & $\mathrm{N} / \mathrm{A}$ & $\mathrm{N} / \mathrm{A}$ & $\mathrm{N} / \mathrm{A}$ \\
\hline Queen & -69 & -76 & -61 & 3 & 3 & 3 & -16 & 32 & 6 & 6 \\
\hline ACX 209 & $\mathrm{~N} / \mathrm{A}$ & $\mathrm{N} / \mathrm{A}$ & $\mathrm{N} / \mathrm{A}$ & $\mathrm{N} / \mathrm{A}$ & $\mathrm{N} / \mathrm{A}$ & 10 & -7 & 30 & 4 & 3 \\
\hline Cadice & $\mathrm{N} / \mathrm{A}$ & $\mathrm{N} / \mathrm{A}$ & $\mathrm{N} / \mathrm{A}$ & $\mathrm{N} / \mathrm{A}$ & $\mathrm{N} / \mathrm{A}$ & -4 & -15 & 9 & 3 & 3 \\
\hline Clovis & $\mathrm{N} / \mathrm{A}$ & $\mathrm{N} / \mathrm{A}$ & $\mathrm{N} / \mathrm{A}$ & $\mathrm{N} / \mathrm{A}$ & $\mathrm{N} / \mathrm{A}$ & 12 & -13 & 50 & 3 & 3 \\
\hline Ma Belle & $\mathrm{N} / \mathrm{A}$ & $\mathrm{N} / \mathrm{A}$ & $\mathrm{N} / \mathrm{A}$ & $\mathrm{N} / \mathrm{A}$ & $\mathrm{N} / \mathrm{A}$ & 30 & 9 & 60 & 3 & 3 \\
\hline Marquis & $\mathrm{N} / \mathrm{A}$ & $\mathrm{N} / \mathrm{A}$ & $\mathrm{N} / \mathrm{A}$ & $\mathrm{N} / \mathrm{A}$ & $\mathrm{N} / \mathrm{A}$ & 1 & -11 & 13 & 3 & 3 \\
\hline Outsider & $\mathrm{N} / \mathrm{A}$ & $\mathrm{N} / \mathrm{A}$ & $\mathrm{N} / \mathrm{A}$ & $\mathrm{N} / \mathrm{A}$ & $\mathrm{N} / \mathrm{A}$ & 4 & 1 & 8 & 3 & 3 \\
\hline Samurai & $\mathrm{N} / \mathrm{A}$ & $\mathrm{N} / \mathrm{A}$ & $\mathrm{N} / \mathrm{A}$ & $\mathrm{N} / \mathrm{A}$ & $\mathrm{N} / \mathrm{A}$ & 5 & 0 & 10 & 4 & 3 \\
\hline Super Sweet 860 & $\mathrm{~N} / \mathrm{A}$ & $\mathrm{N} / \mathrm{A}$ & $\mathrm{N} / \mathrm{A}$ & $\mathrm{N} / \mathrm{A}$ & $\mathrm{N} / \mathrm{A}$ & -19 & -42 & 13 & 3 & 3 \\
\hline Yellow Bell & $\mathrm{N} / \mathrm{A}$ & $\mathrm{N} / \mathrm{A}$ & $\mathrm{N} / \mathrm{A}$ & $\mathrm{N} / \mathrm{A}$ & $\mathrm{N} / \mathrm{A}$ & -11 & -21 & 3 & 6 & 4 \\
\hline Yolo Wonder & $\mathrm{N} / \mathrm{A}$ & $\mathrm{N} / \mathrm{A}$ & $\mathrm{N} / \mathrm{A}$ & $\mathrm{N} / \mathrm{A}$ & $\mathrm{N} / \mathrm{A}$ & 14 & -2 & 32 & 4 & 3 \\
\hline
\end{tabular}

